\title{
SHORT CONSIDERATIONS ON GLASS BEAKERS DISCOVERED IN THE SÂNTANA DE MUREŞ ENVIRONMENT BETWEEN THE CARPATHIANS AND PRUTH
}

\author{
Costin Croitoru
}

\section{Considerații sumare privind paharele din sticlă descoperite în mediul Sântana de Mureş dintre Carpați şi Prut}

De ceva vreme studiul recipientelor de sticlă se bucură de o atenție sporită din partea cercetătorilor, aceste artefacte fiind supuse unor analize dintre cele mai diverse, ce tind să pună în lumină din ce în ce mai elocvent adevărata importanță pe care anticii o acordau materialului vitric. Faptul că cercetările arheologice scot la iveală vase de sticlă specifice unor anumite ateliere sau zone de răspândire nuanțează în bună măsură cunoştințele pe care le deținem în legătură cu relațiile comerciale şi de multe ori politice ale comunităților din teritoriul de la est de Carpați. Totodată, studierea morfologiei acestor piese, a decorului deosebit de variat - uneori dovadă al unui simț estetic uimitor, decodifică nivelul remarcabil la care ajunsese acest meşteşug în antichitate, fără doar şi poate datorat şi cererii care exista în domeniu.

Scopul acestui material a fost acela de a aduna şi interpreta, pe cât posibil exhaustiv, toate informațiile asupra descoperirilor de pahare din sticlă, fortuite sau provenind din siturile arheologice cercetate pe teritoriul cuprins între Carpați şi Prut. Iniţiativa s-a dovedit a fi mult mai dificilă decât ne-am fi aşteptat. Informația, sintetizată în corpusul descoperirilor din partea finală, provine din studiile şi articolele publicate până acum şi prezintă numeroase lacune, iar situația are câteva explicații. Pe de o parte, multe din vasele de sticlă, îndeosebi acelea cu pereți foarte subțiri, aflate uneori în stare de conservare mediocră chiar din momentul descoperirii, au fost fie numai amintite, fie menționate în treacăt, cu detalii sumare sau doar prin ilustrație, ceea ce, de cele mai multe ori, face imposibilă încadrarea lor tipologică şi cronologică. Nici anumite elemente morfologice ori relative la modul de realizare a recipientelor lucrate din material vitric n-au fost semnalate decât rareori cu date complete şi ilustrație de bună calitate. De obicei lipsesc detaliile referitoare la contextul arheologic, tehnologia de lucru, caracteristicile materiei prime şi modul de realizare a ornamentelor. O datare foarte precisă a diverselor tipuri de artefacte de sticlă este destul de dificilă în stadiul actual de cercetare, întrucât nu dispunem încă nici de o cronologie bine pusă la punct pentru siturile în cadrul cărora au fost identificate. Dificultăţile sunt create aşadar şi de nesiguranţa ce se menţine în ceea ce priveşte încadrarea tipologică precisă a unora din recipiente, ca şi de contextul de descoperire destul de neclar pentru unele dintre ele.

Pe de altă parte, aşa cum rezultă din bibliografia fiecărei piese, multe dintre ele au fost publicate de către cercetători străini, fapt ce ilustrează încă o dată „atenția” de care s-au bucurat vasele de sticlă din această perioadă în istoriografia românească. În atare condiții, în mod evident, nu se pot face referiri decât la tipologiile ,străine”.

Pentru perioada menționată se remarcă o abundență a materialului vitric în spațiul dintre Carpați şi Prut. Recipiente de sticlă au fost semnalate pe cuprinsul a 29 de situri arheologice, aflate în stadii diferite de cercetare, atât în aşezări (10 puncte arheologice însumând 16 recipiente de sticlă) cât şi în necropole (19 puncte arheologice însumând 84 recipiente de sticlă), procentul majoritar fiind net în favoarea celor din urmă, numai vasele de sticlă identificate la Mihălăşeni şi Bârlad-Valea Seacă însumând aproximativ $60 \%$ din totalul descoperirilor efectuate în spațiul care ne interesează. Desigur pentru o asemenea realitate poate pleda şi stadiul avansat al cercetărilor, respectiv al publicării din cadrul acestor două stațiuni arheologice, totuşi diferența deloc de neglijat poate conduce către anumite interpretări. O aşezare, cea de la Iaşi-Cartier Nicolina, se situează abia pe locul trei, la diferenţă foarte mare, 
reprezentând „numai” $6 \%$ din cuantumul descoperirilor de recipiente de sticlă. Nu este mai puțin adevărat faptul că, pentru siturile în care s-au efectuat doar cercetări de teren, încadrarea în categoria ansamblurilor funerare sau de locuit ar putea suferi corijări pe măsura aprofundării lor.

Key words: Moldavia, Sântana de Mureş, glass beakers, typology, decorantion.

In recent years, glassware research benefited of scholars' increased focus, while such artefacts underwent most diverse analyses that aimed at emphasizing, rather eloquently, the real importance that the classics granted to glass material. Archaeological excavations led to the discovery of glassware specific to both certain workshops and dissemination areas and as a result, the knowledge on trade relations and often, political relations in the territory east of the Carpathians improved. Concurrently, the study of their morphology and rather varied decoration - occasionally proving an astonishing aesthetic taste, translated into the remarkable level that glassware making reached in Antiquity, unquestionably due to the demand in the field.

Herein we attempted to gather and interpret, as systematically as possible, all information on discoveries of glass beakers coming from either chance finds or archaeological sites explored in the territory between the Carpathians and Pruth River. Our enterprise proved more difficult as expected. The information, synthesised in the catalogue of finds by the end of the paper, comes from studies and articles already published and presents numerous flaws that could be explained to a certain extent. On one hand, many of the glass recipients, especially very thin-walled glassware, occasionally already in a poor state when found, are either hinted or only mentioned, little detailed or only illustrated, hence typologies and chronological dates are rather impossible to draw. Furthermore, morphological elements or aspects related to the manufacturing technique of the glass recipients are hardly ever comprehensively indicated or well illustrated, whilst details referring to the archaeological context, working technology, characteristics of the raw material and ornamentation means are usually lacking. The accurate dating of various types of artefacts is considerably difficult under current circumstances since there is no fine established chronology for the sites of origin. Consequently, difficulties are due to continued uncertainties regarding the correct typological framing of certain recipients and to rather frequent unclear contexts of discovery.

On the other hand, as indicated by bibliography, many of the pieces were published by foreign scholars, moreover confirming the "attention" that glassware of the period benefited in Romanian historiography ${ }^{1}$. Subsequently, one may make no other references than to "foreign" typologies.

During the mentioned period, the glass material is abundant in the area between the Carpathians and Pruth River. Glass recipients were signalled within 29 archaeological sites, both settlements (10 archaeological points with up to 16 glass recipients) as well as necropolises (19 archaeological points with up 84 glass recipients), the percentage being decidedly favourable to the latter, as only glassware identified at Mihălăşeni and Bârlad-Valea Seacă sum up to $60 \%$ of the total finds from the region of interest. Obviously, the advanced state of research, respectively publishing of materials coming from the two archaeological sites pleads for such realities, yet the noticeable difference may also lead to certain interpretation. A settlement like the one from Iaşi-Cartier Nicolina ranks only third, at significant distance and representing "only" $6 \%$ of glass recipients share of finds. Nonetheless, the fact that sites

\footnotetext{
${ }^{1}$ The first synthesis, dedicated to a glassware category identified in Romania and dated during the 3rd - 5th centuries AD was issued only in 2007, Pánczél, Dobos 2007, 67-97.
} 
explored by only field walking would be framed subsequent to further investigations, as either funerary or dwelling assembles, is also true.

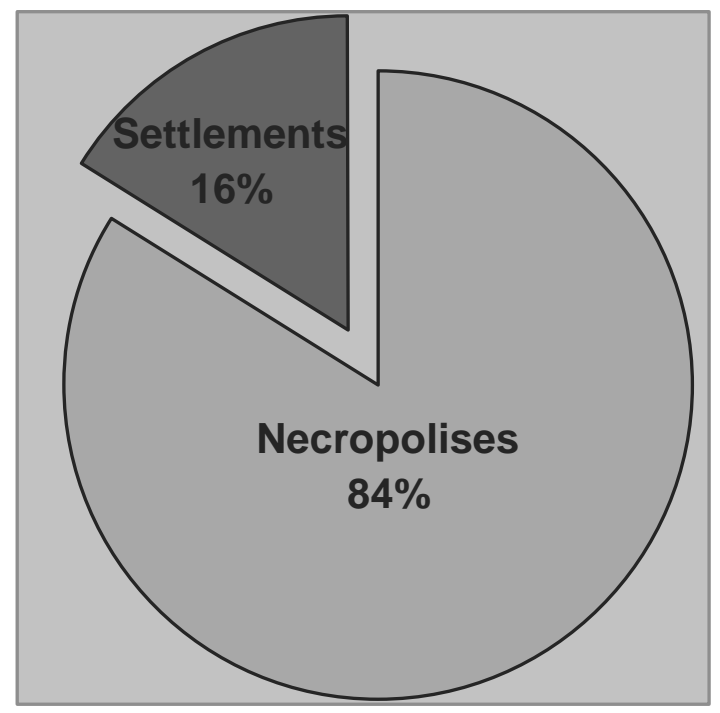

Fig. 1. Distribution of glassware upon site categories

Regarding the distribution upon types of funerary assembles, 50 glass beakers were identified in inhumation graves and 20 inside cremation graves, while data on other 14 items does not indicate any point of origin

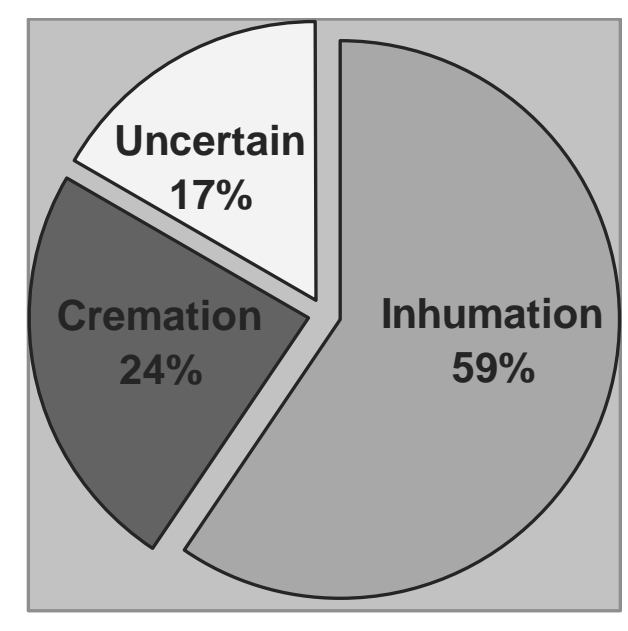

Fig. 2. Distribution of glassware upon burial categories

We should further emphasize the probability degree of percentage approaches since certain recipients might be associated to the general category of beakers only hypothetically. Therefore, another issue related to the study of glass material is the advised differentiation between beakers and cups, considering that in general the two notions are not always well established. Height and maximum diameter ratio represents the main separation criterion in the case of the two recipient categories ${ }^{2}$. When height exceeds diameter, the recipient is ascribed to

\footnotetext{
${ }^{2}$ Straume 1987, 20; Ioniţă 2001-2002, 223.
} 
the beaker category, while vessels with a smaller height or equal to the diameter are classified as cups. Obviously, the mentioned criterion may be applied to complete vessels or to vessels whose general form can be restored with sufficient precision. Regarding the recipients whose morphologies cannot be established, their assignment to one or the other category is difficult and uncertain, like the case of some vessels that shall be referred to in the catalogue of finds.

For instance, we may exemplify by recipients from Cârligi (catalogue no. 2), Mihălăşeni (catalogue no. 3-6, 12), Miorcani (catalogue no. 20-21), Iaşi-Fabrica de Cărămizi (catalogue no. 38), Iaşi-Cartier Nicolina (catalogue no. 39-42, 44) and Bârlad-Valea Seacă (catalogue no. 69, 88, 97-98) represented by small fragments, which, upon decoration seem to principally belong to the beaker category although elements of certainty are lacking. Additionally, the fragmentary glass recipients from Mihălăşeni (catalogue no. 13), Poieneşti (catalogue no. 57) and Băiceni (catalogue no. 35-36) are worth mentioning. In the case of the latter, the conserved elements belong exclusively to vessel upper parts that might have composed cups as well, although no close analogies could be identified given that limited parts of decoration elements have been preserved. Other pieces, like those from Ripiceni (catalogue no. 23), Truşeşti (catalogue no. 26), Cavadineşti (catalogue no. 31), Holboca (catalogue no. 37), Spinoasa (catalogue no. 46), Vânători (catalogue no. 47), Dolheştii Mari (catalogue no. 50), Bozia (catalogue no. 53), Obîrşeni (catalogue no. 55), Pogoneşti (catalogue no. 56), Polocin (catalogue no. 58) and Bârlad-Valea Seacă (catalogue no. 59-62, 70-75, 77-81, 87, 91) are only mentioned, without supplementary details or illustration. It seems that at Ripiceni and Pogoneşti several (?) glass recipients were discovered.

Lastly, no appreciations can be made in the case of the completely damaged glass material unearthed at Călugăreni (catalogue no. 1), Mihălăşeni (catalogue no. 11) and BârladValea Seacă (catalogue no. 83-86, 89-90, 95) except for such judgment that would account for the amount of discoveries.

The precision of framing the 100 glass recipients designated as beakers is questionable in the case of a few exemplars and no hypotheses may be sketched for the lack of a thorough study regarding the preserved original pieces.

Under such circumstances, considerations relative to the glass beaker typology are rather difficult to outline and imperatively require further corrections. From morphological and specific decoration points of view and based on similar recipients identified in other areas, the beakers discovered in Moldova may classify as follows:

Type A. (types Eggers 230; Ekholm IIBc; Kowalk; Eketorpsglas 3/11; Straume I)

This category is illustrated by complete or restorable vessels unearthed at Mihălăşeni (catalogue no. 16), Barcea (catalogue no. 29), Lunca (catalogue no. 32-34), Polocin (catalogue no. $58 a-b$ ) and Bârlad-Valea Seacă (catalogue no. 64, 76, 82). Other fragments found at IaşiCartier Nicolina (catalogue no. 39-40, 44) and Bârlad (catalogue no. 88, 98) may belong to the same type, unless their original, yet non-restorable sizes would plead for their affiliation to the cup category. Complete exemplars known in the area between the Carpathians and Pruth River come exclusively from inhumation graves (probably except for a beaker discovered at Lunca catalogue no. 34, identified in the necropolis debris).

This beaker type is well known and largely spread. Exemplars were identified in the Scandinavian Peninsula, Poland, Germany and Hungary ${ }^{3}$. In Muntenia, similar vessels were signalled at Copuzu ${ }^{4}$, Spanțov $\left(\mathrm{G}_{10}, \mathrm{G}_{67}\right)^{5}$, Alexandru Odobescu $\left(\mathrm{G}_{11}\right)^{6}$, Pietroasele $\left(\mathrm{G}_{1}\right)^{7}$,

\footnotetext{
${ }^{3}$ Straume 1987, 130, Karte 2.

${ }^{4}$ Muşețeanu 1986, 209-220.
} 
Mogoşani ${ }^{8}$, etc. In west Romania, the only exemplar comes from the damaged grave at ŞeitinImaş ${ }^{9}$. They also mainly appear in the eastern area of Sântana de Mureş environment, at Budeşti $^{10}$, Žovnin $^{11}$, Dănceni ${ }^{12}$, Žuravka $^{13}$, Gnatki ${ }^{14}$, etc.

The general shape is cylindrical, exhibiting a wide opening, slightly out-turned rim delimited from the rest of the body by a fine groove (except for the exemplar from BârladValea Seacă, catalogue no. 64, yet a restoration error could also be taken into consideration?), the outer surface is ornamented with four rows of cells placed vertically, while the base is either straight or slightly rounded. The glass is thick, greenish or yellowish, the sizes of the recipients are similar and the height of complete exemplars on which we have information varies between 12 and 13 centimetres.

Taking into account several available exemplars, E. Straume distinguishes two variants, also depending on the position and quality of oval decorations (variant $\mathrm{IA}^{15}$, represented in Moldova by finds from Mihălăşeni catalogue no. 16 and Barcea catalogue no. 29 and respectively variant $\mathrm{IB}^{16}$, represented by discoveries at Lunca catalogue no. 32-34, Bârlad-Valea Seacă catalogue no. 76, 82).

In our space of reference, two other recipients belong to the same general shape, yet the decoration is either missing (?) or partial (?) as the case of the recipient uncovered at Bogdăneşti (catalogue no. 52, the illustration is not indicative - as much as one may distinguish, a single register of ovals slightly is placed above the central area) with very thin walls, or is represented by two fine grooves in the upper part, as the case of the recipient found at Bârlad-Valea Seacă (catalogue no. 67).

Chronologically and based on the context of discovery of similar pieces, recipients of the type emerge starting with stage $\mathrm{C} 2$, yet significantly distribute during stage $\mathrm{C} 3$ (approximately 310/320 - 375 AD), with the remark that if variant IA recipients are earliest (the end of stage $\mathrm{C} 2$ - end of stage $\mathrm{C} 3$ ), the exemplars of IB variant may reach stage $\mathrm{D} 1{ }^{17}$. The distribution of this type was attempted chronologically associated with the "development" or "classical" stage of the Sântana de Mureş-Černjachov culture ${ }^{18}$. Since the chronological boundaries of the above mentioned culture were not sufficiently clarified, any hypotheses are speculative. The chronological extension of this type of recipients found in Scandinavia to those identified in Sântana de Mureş environment is also questionable. Subsequently, it was specified that type IA beakers found in the east of the Continent would rather date from the first $\mathrm{C} 3$ stage, while those of IB type especially in stage C3, their emergence until stage D1 being debatable ${ }^{19}$.

\footnotetext{
${ }^{5}$ Mitrea, Preda 1966, 22, fig. 20; 39, fig. 94/3. The exemplar discovered in $\mathrm{G}_{67}$ may only be an imitation of type A beakers, acc. Pánczél, Dobos 2007, 69, no. 20, pl. III/20.

${ }^{6}$ Mitrea, Preda 1966, 99, fig. 238/7, 239/5.

${ }^{7}$ Diaconu, Tzony, Constantinescu, Drâmbocianu 1977, 29, fig. 25/5.

${ }^{8}$ Pánczél, Dobos 2007, 80, no. 16 with references.

${ }^{9}$ Dörner 1970, fig. 14/3.

${ }^{10}$ Vornic 2006, 212, type 2, fig. 15/4, 6, 8; 110/7, 11, 18, 24; 127/1-7, 9, 15; 129/8.

${ }^{11}$ Kropotkin 1970, fig. 79/5.

12 Rafalovič 1986, pl. XXXIX/8.

${ }^{13}$ Symonovič 1964 , fig. $1 / 4$.

${ }^{14}$ Kropotkin 1970, fig. $77 / 5$.

${ }^{15}$ Straume 1987, 28-29, Taf. 2; Table 2.

${ }^{16}$ Straume 1987, 29-30, Taf. 3; Table 3.

${ }^{17}$ Eggers 1951, 92-94; Ekholm 1965, 3, 20-21; Rau 1975, Abb. 6; Näsman 1984, 49-53; Straume 1987, 28-31; Godłowski 1970, 108; Godłowski 1992, 50; Tejral 1992, 229, 246; Pánczél, Dobos 2007, 69.

${ }^{18}$ Rau 1972, 134; Tejral 1992, 235, Pánczél, Dobos 2007, 73.

${ }^{19}$ Ioniță, Straume 1993, 167; Ioniță 1994-1994, 155.
} 
The diffusion of these recipients on such a large area is probably due to several workshops, whilst the amassment of discoveries in eastern areas may indicate the presence of several exemplars even in Barbaricum ${ }^{20}$, yet such a fact must be proven by further research.

Type B. (types Eggers 236; Ekholm IICa; Straume VI)

Thus far this category is exemplified by a single exemplar identified at Mihălăşeni (catalogue no. 17). Like in our reference area, such exemplars are quite rare. Analogies come from Bremsnes ${ }^{21}$ and Gjerla ${ }^{22}$, both in Norway. Their shape is similar to the above discussed vessels, yet the decoration is different. The decoration made of four registers of ovals separated by fine grooves, with similarly sized ovals in the upper and third registers is specific. Considering known analogies, the recipients may date in the chronological interval comprised between stages C3 - D1 (310/320 - $400 \mathrm{AD})$.

Type C. (types Eggers 237; Ekholm IIAb-IIBc; Eketorpsglas 6/21; Straume VIIA-B)

Type $\mathrm{C}$ is represented by a large number of pieces and its large distribution is also confirmed by discoveries east of the Carpathians where they represent the most numerous category; in fact, except for the Scandinavian Peninsula, most exemplars come from the Sântana de Mureş-Černjachov environment. Taking into account known analogies, this type of recipients may be generally dated within the chronological interval comprised between stages $\mathrm{C} 3$ - D1 $(310 / 320-410 \mathrm{AD})^{23}$, based on the inventory they were discovered beside and related to late stages of Sântana de Mureş culture ${ }^{24}$. The origin of such thick-walled beakers is uncertain. Hypotheses consider eastern and Syrian workshops, as well as a local origin, the Sântana de Mureş cultural environment ${ }^{25}$.

Due to the large number of such recipients, a few distinctions may be made within the same category, especially linked to the specific decoration (the ovals shape, cell-like or oval) expressively noticed by E. Straume ${ }^{26}$, for which reason we shall adopt similar general framework:

1. Type $c_{1}$ beakers (Straume VII A; Lund-Hansen 25) uncovered at Mihălăşeni (catalogue no. 7, 9, 18), Murgeni (catalogue no. 54) and Bârlad-Valea Seacă (catalogue no. 100). Other fragments coming from Iaşi-Fabrica de Cărămizi (catalogue no. 38), Iaşi-Nicolina (catalogue no. 42) and Bârlad-Valea Seacă (catalogue no. 69, 97) seem to pertain to the same category. This sub-group is characterised by the general conical shape of the vessels, narrow base and wide opening. The specific decoration, generally inserted between two grooves - one placed immediately beneath the rim, the other in the lower part of the recipient is represented by three (Mihălăşeni, catalogue no. 7, 9) or four rows of ovals (Mihălăşeni, catalogue no. 18), linked one to the other and joined so that the inner ovals are transformed into hexagonal "facet" cuts. In the case of the identified exemplars, between the upper groove and register of ovals, an additional row of smaller ovals is placed slightly rarely and horizontally. A variant of the same type may be represented by the fragment pertaining to the lower part of a beaker found at IaşiNicolina (catalogue no. 43). The general shape is identical, while slight differentiations emerge in decoration: the three rows of ovals although not joined, yet close one to another, seem to render similar "hexagonal facet cuts". A close analogy is found at Archiud-Hânsuri ${ }^{27}$ (variant?), exhibiting slightly distanced ovals.

\footnotetext{
${ }^{20}$ Rau 1972, 170; Straume 1987, 61; Ščukin 2005, 180.

${ }^{21}$ Eggers 1951, 91, no. 323; Ekholm 1965, 22, no. 90; Straume 1987, 77, no. 2, Taf. 6/15:1.

${ }^{22}$ Ekholm 1965, 22, no. 88; Straume 1987, 85, no. 15, Taf. 6/2.

${ }^{23}$ Ekholm 1965, Abb. 5; Rau 1972, 170; Ioniță 1986a, 305-306; Straume 1987, 38; Gomolka-Fuchs 1999, 139.

${ }^{24}$ Tejral 1992, 235-236; Pánczél, Dobos 2007, 73.

${ }^{25}$ Straume 1987, 60, 62.

${ }^{26}$ Straume 1987, 36-38, no. 15 , Taf. 7-8.

${ }^{27}$ Gaiu 1999, 269, 286, fig. 16/2.
} 
The beakers of the discussed type were also identified at Târgşor ${ }^{28}$ or in the east, at Budeşti $^{29}$, Chişcăreni ${ }^{30}$, etc.

2. Type $c_{2}$ beakers (Straume VII B; Lund-Hansen 24) discovered at Mihălăşeni (catalogue no. 10, 14) and Bârlad-Valea Seacă (catalogue no. 65). A variant of the same type may be the exemplar from Bârlad (catalogue no. 66).

The general shape is similar to that of the preceding type, while the decoration preserves the mentioned lines: inserted between two grooves - one placed immediately under the rim, the other in the lower part of the recipient, is represented by four rows of ovals (in the case of pieces coming from our space of reference), while this time, the difference consists in the fact that they are no longer joined, but only brought near, so the impression of hexagonal facet cuts is missing. Another exemplar coming from Bârlad-Valea Seacă (catalogue no. 93) could belong to the same variant ${ }^{31}$ (we have our own doubts concerning the restoration proposition of the beaker shape in the lower part). In Romania, recipients of the same type come from Alba Iulia ${ }^{32}$, Călăraşi ${ }^{33}$. In the east, they also appear at Budeşti ${ }^{34}$, Černjachov $^{35}, \breve{Z u r a v k a}^{36}$, Panticapeum ${ }^{37}$, etc.

Type D. (types Eggers 238; Eketorpsglas 6/24; Straume VIII)

They were identified at Miorcani (catalogue no. 22), Barcea (catalogue no. 30), Izvoare (catalogue no. 48) and Bârlad-Valea Seacă (catalogue no. 63, 99). The fragment from Tocileni (catalogue no. 24) seems to have belonged to a recipient from this category ${ }^{38}$. Analogies are found especially in the Scandinavian Peninsula and rarely in the rest of the Continent ${ }^{39}$ where are interpreted as Roman imports manufactured in the Eastern provinces of the Empire. The general shape of the type is conical, ended in a short foot. The decoration is made within two asymmetrical registers, separated by a richly ornamented intermediary field, usually made of circles or cut lines inserted between two grooves. The decoration of the lower register starts from the immediate vicinity of the foot and is represented by four large ovals made of glass fabric and applied in relief, occupying more than half of the wall. Their asymmetrical position gives the impression of facet cuts. Occasionally in the superior part, in between ovals, four small knobs are placed. Based on established analogies, they date between the chronological interval comprised between stages C3 - D1 (310/320 - 410 AD) ${ }^{40}$.

Considering the decoration of the upper register, in the case of the exemplars coming from the analysed area, two variants may be distinguished:

1. Type $\mathrm{d}_{1}$ beakers. The exemplars discovered at Tocileni (catalogue no. 24), Barcea (catalogue no. 30) and Bârlad-Valea Seacă (catalogue no. 63) exhibit an inscription applied on

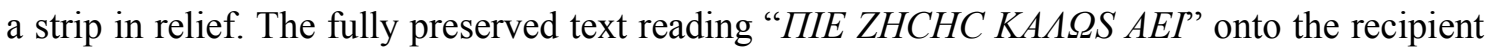
from Barcea may be possibly used for the reconstruction of the other fragments. The beakers from Miorcani (catalogue no. 22) and Bârlad-Valea Seacă (catalogue no. 99) may belong to the same category, yet since they lack precisely the upper part, we can only make suppositions.

\footnotetext{
${ }^{28}$ Diaconu 1965, pl. CIX/7. The exemplar is considered by Pánczél, Dobos 2007, 83, no. 36, a type Straume VII B variant.

${ }^{29}$ Vornic 2006, 213, type 4, fig. 33/7; 36/1; 67/19; 126/1-2, 4-6; 130/2-3.

${ }^{30}$ Levinschi 1997, fig. 4/7.

${ }^{31}$ Similar framing to Pánczél, Dobos 2007, 82, no. 34, pl. IV/34.

32 Băluță 1979, 198, fig. 4/3.

${ }^{33}$ Culică 1974, 455, fig. 1/1.

${ }^{34}$ Vornic 2006, 213, type 5, fig. 110/15; 126/7-8, 10, 15; 127/12; 130/1.

${ }^{35}$ Kropotkin 1970, 105, fig. 76/1.

${ }^{36}$ Symonovič 1964, 9-10, fig.2.

${ }^{37}$ Sorokina 1962, 232, fig. 13/6; 16/5.

${ }^{38}$ Similar framing to Pánczél, Dobos 2007, 84, no. 41, pl. V/41.

${ }^{39}$ Straume 1987, 38-40.

${ }^{40}$ Näsman 1984, 86; Straume 1987, 39-40.
} 
Similar inscriptions appear on recipients discovered in Norway, Denmark, Hungary or Russia ${ }^{41}$. In Romania, only the exemplars identified in Moldova are known.

2. Type $d_{2}$ beakers. There are recipients where this secondary register is missing, like the case of the exemplar identified at Izvoarele (catalogue no. 48). Once again, the beaker from Bârlad (catalogue no. 99) may belong to the same variant, yet since the upper part is missing we can only make suppositions, as it may have well been one of the exemplars bearing inscription. In Muntenia, a complete exemplar was found at Independența $\left(\mathrm{G}_{20}\right)^{42}$. Fragmentary pieces come from Bratei ${ }^{43}$, while in the east they were unearthed at Budeşti ${ }^{44}$, Comrat $^{45}$, Kerč ${ }^{46}$, etc.

Type E. (types Straume IX; Eketorpsglas 6/23)

A single exemplar was identified at Izvoarele (catalogue no. 49) ${ }^{47}$. This category is characterised by the general conical shape of the vessels, narrow base and wide opening. The specific decoration, generally inserted between two grooves - one placed immediately under the rim, the other above the short foot, consists of three rows of inlaid ovals, linked one to another. The first, are the largest and are rounded in the upper part, while in the lower part they end in angle, so that the following row gives the impression of hexagonal facet cuts. A third row, the lower and the smallest, is formed only of oval cuts that seem to become round. Occasionally, as the case of our exemplar, between the larger, upper ovals also appear small circular knobs. Analogies for such recipients are found in the Scandinavian Peninsula ${ }^{48}$, while in our space of reference they are extremely rare, in fact, except for the recipient at Izvoarele, fragments that might belong to the category under discussion are signalled only at Budeşti ${ }^{49}$, Kurniki ${ }^{50}$ or Jakuševcy ${ }^{51}$. For reasons related to the dissemination and density of beakers, it was considered they originate from Scandinavian glassware making workshops ${ }^{52}$. Such recipients seemed to have been in use in the chronological interval between stages C3 - D1 (310/320 - 400 AD), although in archaeological sites from Norway or Sweden they amass in complexes dated rather in stage $\mathrm{D}^{53}$. The inventory of $\mathrm{G}_{\mathrm{IX}}$ from Izvoarele pleads for the dating of the beaker in the interval comprised between the last quarter of the $4^{\text {th }}$ - beginning of the 5 th centuries $\mathrm{AD}^{54}$.

Type F. (types Straume X; Isings 106 d)

They were identified at Mihălăşeni (catalogue no. 15, 19), Barcea (catalogue no. 2728), Lețcani (catalogue no. 45), Moara (catalogue no. 51) and Bârlad-Valea Seacă (catalogue no. 92). Another fragmentary recipient comes from Bârlad-Valea Seacă (catalogue no. 68) seems to belong to the same type. Beakers are made of thin glass, by blowing, are conical, slender and tall. Upon the relatively simple decoration, they may be divided in several variants:

\footnotetext{
${ }^{41}$ Eggers 1951, 95, 78, no. 11, 416; Ekholm 1965, 22, 24, no. 95, 118, Abb. 2/95, 3/118; Symonovič 1966, 105-109; Rau 1972, no. 71; Näsman 1984, 61; Straume 1987, 100-101, 121, 123, 127, 131, no. 44, 91, 96, 131, 149; Țau, Nicu 1985, 166; Gomolka-Fuchs 1999, 139, Abb. 7/1, 4-5.

${ }^{42}$ Mitrea, Preda 1966, 143, fig. 134, 267 (type III beakers); Gomolka-Fuchs 1999, Abb. 7/3.

${ }^{43}$ Bârzu 1973, 63.

${ }^{44}$ Vornic, 2006, 214, type 7, fig. 128/1.

${ }^{45}$ Rikman 1972, fig. 6/17.

${ }^{46}$ Gavrituchin 1999, 57.

${ }^{47}$ Pánczél, Dobos 2007, 84, no. 42, pl. VI/42, frames the fragment coming from Iaşi-Nicolina (catalogue no. 42) in the Straume IX category. As suggested, same fragment may well come from a type Straume VII A beaker.

${ }^{48}$ Ekholm 1965, pl. 1/17; no. 17-20, 106, 111; Näsman 1984, 150, type 23, Karta 6; Straume 1987, 40, no. 18, 21, 22, $39,72$.

${ }^{49}$ Vornic, 2006, 214, type 6, fig. 126/3, 9, 12; 128/12.

${ }^{50}$ Magomedov 1999, fig. 15/1.

${ }^{51}$ Gavrituchin 1999, 54, 66.

${ }^{52}$ Straume 1987, 40-41.

${ }^{53}$ Rau 1972, Abb. 37; Näsman 1984, 61; Straume 1987, 40; Gavitruchin 1999, 54, 86.

${ }^{54}$ Alexianu, Ellis 1995, 297-298.
} 
1. Type $f_{1}$ beakers. (type Gavrilovka $35^{55}$ ) made of thin glass, generally transparent or green-yellowish, decoration made of three (Mihălăşeni, catalogue no. 15, 19), rarely two (Bârlad-Valea Seacă, catalogue no. 92) fine grooves placed in the upper part. Similar exemplars are relatively well known in Muntenia, being discovered at Mogoşani $\left(\mathrm{G}_{8}, \mathrm{G}_{52}\right)^{56}$, Gherăseni $\left(\mathrm{G}_{59}\right)^{57}$, Spanțov $\left(\mathrm{G}_{13}, \mathrm{G}_{41}\right.$ ?), Izvoru $\left(\mathrm{G}_{6}, \mathrm{G}_{7}\right)^{58}$, Mărtineşti ${ }^{59}$, etc., or in the east at Mălăiești $^{60}$, Budeşti ${ }^{61}$, Dănceni ${ }^{62}$, Slobozia-Chişcăreni ${ }^{63}$, etc. Recipients belonging to the same general shape might not have any ornamentation, like the exemplar from Lețcani (catalogue no. 45). In Muntenia, a similar recipient was discovered at Copuzu $\left(\mathrm{G}_{24}\right)^{64}$, but such exemplars are known in the north of the Black Sea ${ }^{65}$ as well. The idea that thin-walled recipients are import pieces from the Roman world is generally accepted; they reach the Sântana environment especially from Eastern provinces and their chronology is restricted to the interval comprised between the second half of the 4 th - beginning of the 5th centuries $\mathrm{AD}^{66}$.

2. Type $f_{2}$ beakers. Their decoration consists of three fine grooves positioned in the upper part, while in the centre four large ovals (Nuppenverzierung) and four groups of three smaller dark blue ovals placed on two levels are displayed. The upper register comprises two larger ovals, placed symmetrically, inlaid by two groups of three smaller ovals; the lower register exhibits the same arrangement, with the groups of smaller ovals placed backwards. This type is exemplified by the discovery at Bârlad-Valea Seacă (catalogue no. 94). Such recipients are rather rare $^{67}$. The decoration of the beaker found within the above mentioned necropolis may be interpreted in the same manner (catalogue no. 96) ${ }^{68}$.

3. Type $f_{3}$ beakers. (type Eketorpsglas $8 / 37$ ), ornamented with bi-chrome ribs or ribs similar to the glass of which the vessel is manufactured, applied in relief. Two beakers decorated as such were identified at Barcea (catalogue no. 27-28). Recipients of the type are rather scarce and similar items come from the north of the Black Sea at Kosanovo and Žurovka or in the west at Holm and Thiétreville ${ }^{69}$. The decoration probably follows the decoration of older recipients of Poieneşti-Dumeştii Vechi type. A glass fragment uncovered at Băiceni $\left(\mathrm{S}_{22}\right)$ which upon decoration, belongs to the last category according to the restoration proposed by Godruna Gomolka-Fuchs, was erroneously included in the catalogue of glass material specific to Sântana de Mureş culture ${ }^{70}$, being identified with certainty within the inventory of a settlement of the "Free Dacians" truncated-cone in shape, having a larger base and ending in a short circular foot, the beaker

\footnotetext{
${ }^{55}$ Rau 1972, 181, fig. 76c.

${ }^{56}$ Diaconu 1969, 379, pl. 5/10, 13.

${ }^{57}$ Constantinescu 1992, 197, fig. 2/2.

${ }^{58}$ Mitrea, Preda 1966, 143, fig. 216, 178/1, 179/1 (type I beaker).

${ }^{59}$ Bobi 1985, 208, fig. 10/1; Gomolka-Fuchs 1999, p. 136, Abb. 5/5.

${ }^{60}$ Fedorov 1960, 287, fig. 12.

${ }^{61}$ Vornic 2006, 211-212, type 1, fig. 101/1.

${ }^{62}$ Rafalovič 1986, pl. XXII/9.

${ }^{63}$ Levinschi 1997, fig. 4/9.

${ }^{64}$ Muşețeanu 1986, 211, pl. 4/15

${ }^{65}$ Sorokina 1962, 104, pl. 40/3.

${ }^{66}$ Kropotkin 1970, 111; Tejral 1987, 16; Barkoczi 1988, 84; Gomolka-Fuchs 1999, 135; Gavrituchin 2000, 265-269, Vornic 2006, 212.

${ }^{67}$ Kovács 1912, 327; Harden 1970, 59; Diaconu 1965, 107.

${ }^{68}$ Pánczél, Dobos 2007, 70, no. 24, pl. III/24 do not exclude that the recipient from $\mathrm{G}_{541}$ belongs to type Straume IV = Eggers 233.

${ }^{69}$ Symonovič 1964, Tab. 1, fig. 2; Kropotin 1970, no. 993; Rau 1972, 181, no. 48, 50, fig. 48/5, 75/13; Näsman 1984 , 85,150 , no. $34,37,41$.

${ }^{70}$ Gomolka-Fuchs 1999, 141, 136, Abb. 5/3.

${ }^{71}$ Ioniță 1982, 61; Ioniță 2000-2001, 236, no. 1.
} 
from Todireni (catalogue no. 25) preserves yet the same specific decoration, although no close analogies could be established with our space of reference (see type Eketorpsglas 8/35 72 or Arnswalde $^{73}$ ). The fragment from Mihălăşeni (catalogue no. 13) has no analogies either, and, alike the exemplar from Todireni ends in a circular foot. There are no clues regarding the upper part of the recipient, which seemed to have exhibited a decoration made of horizontal ovals. It may possibly come from a vessel of shape Isings 108.

Another recipient that seems to be part of the short beakers category, yet which is fragmentary so it may have well pertained to a cup, was identified at Poienești (catalogue no. 57). As much as one may distinguish from the piece illustration (left with no description or details regarding the context of discovery), the decoration seems to follow the example of the variant under discussion, consisting of a glass rib placed windingly in the upper register, as the case of the decoration on the beaker found at $\mathrm{Szob}^{74}$, in Hungary or the beaker fragment (?) unearthed at Ciocâlteni (the Republic of Moldova) ${ }^{75}$.

4. Type $\mathrm{f}_{4}$ beaker. Belonging to the same general shape, discovered at Moara (catalogue no. 51). There are also no analogies for this recipient type, decorated, starting from the inferior part on approximately half of the surface with vertical ribs. In the superior part a horizontal rib applied in relief is displayed. Due to a small fracture in the inferior part, the piece publisher ${ }^{76}$, does not exclude the fact that the recipient might have probably ended in a foot (!?), that would differentiate it from the variant under discussion.

In general, considering the context of discovery and existent analogies, such recipients date from the chronological interval comprised between the stages C3 - D1 (310/320 - 400 AD) ${ }^{77}$.

Type G.

A single exemplar was uncovered at Mihălăşeni (catalogue no. 8). This category is represented by globe-shaped recipients made of thin transparent glass that seem to be close to shape Isings 94 dated largely in the interval comprised between the $3 \mathrm{rd}-4$ th centuries $\mathrm{AD}^{78}$. Morphologically close are the beakers discovered in the necropolises from Scupi and Brigetio, where they appear in contexts dated in the 3rd century $\mathrm{AD}^{79}$. One may not exclude though, the fact that certain exemplars could be earlier, like the one from a grave at Constanța, dated based on a coin from Antoninus Pius ${ }^{80}$. Other exemplars come from late Roman necropolises from Ságvár ${ }^{81}$, Augsburg ${ }^{82}$, Tomis $\left(\mathrm{G}_{43}\right)^{83}$ and Callatis $\left(\mathrm{G}_{148}\right)^{84}$. The latter ensures some dating elements even in later times, being identified beside a knob brooch. The single analogy from the Sântana de Mureş environment comes from Mogoşani $\left(\mathrm{G}_{6}\right)^{85}$.

Taking into consideration their distribution area, thin-walled recipients represent import vessels from the Roman world that reached the Sântana environment mainly from Eastern provinces.

\footnotetext{
${ }^{72}$ Näsman 1984,150 , no. 35 .

${ }^{73}$ Rau 1972, 167, 172, fig. 57.

${ }^{74}$ Näsman 1984, 150, no. 42.

${ }^{75}$ Gomolka-Fuchs 1999, 135, 140, Abb. 4/9.

${ }^{76}$ Emandi 1976, 389-390, fig. 6/4, 9/1, does not exluce a footed - recipient since a base fracture was identified.

${ }^{77}$ Rau 1972, 135-138, fig. 76c; Symonovič 1960, 237, Pl. IX/14; Straume 1987, 41, Taf. 11; Palade 2004, 220.

${ }^{78}$ Isings 1951, 111.

${ }^{79}$ Acc. Lungu, Chera-Mărgineanu 1982, 190.

${ }^{80}$ Bucovală 1968, 54, no. 59 (2nd - 3rd centuries AD). Similar dating to Sorokina 1962, p. 227, fig. 11/1.

${ }^{81}$ Burger 1966, 130, fig. 118.

${ }^{82}$ Keller 1971, 138, 227, pl. 3/13, fig. 38/11.

${ }^{83}$ Lungu, Chera-Mărgineanu 1982, 190, pl. V/22.

${ }^{84}$ Preda 1980, 34, type f, pl. XIII, LXVII.

${ }^{85}$ Diaconu 1970, 18, fig. 5/18.
} 


\section{Catalogue of finds:}

I. Călugăreni (Dămieneşti commune, Bacău county)

Ferma, necropolis, rescue excavations

1. glass beaker damaged during works, small fragments were recovered (note), discovered in an inhumation grave

Bibl.: Mitrea 1979, 175.

II. Cârligi (Filipeşti commune, Bacău county)

Rădi-Hărmăneşti, settlement, systematic digs

2. cream-coloured glass beaker (?), fragmentary, decorated with a groove near the rim and other two below, unknown discovery circumstances

Bibl.: Mitrea 1986, 144, fig. 6/4, 8/10.

III. Mihălăşeni (Mihălăşeni commune, Botoşani county)

Şesul Başeului, necropolis, systematic digs

3. fragmentary glass beaker (?), sizes: $\mathrm{H}=2.5 \mathrm{~cm}$., found in $\mathrm{G}_{28}$ inhumation grave

Bibl.: Şovan 2005, 23, pl. 19C, 3.

4. fragmentary glass beaker (?), thin-walled, sizes: $\mathrm{H}=1.5 \mathrm{~cm}$., unearthed in the filling of $\mathrm{G}_{41}$ inhumation grave

Bibl.: Şovan 2005, 26, pl. 26B, 2.

5. fragmentary greenish glass beaker (?), sizes: $\mathrm{H}=1.5 \mathrm{~cm}$., discovered in $\mathrm{G}_{44}$ cremation grave

Bibl.: Şovan 2005, 27, pl. 28A, 4.

6. thick-walled fragmentary glass beaker (?), partially melt, sizes: $\mathrm{H}=2.1 \mathrm{~cm}$., discovered in $\mathrm{G}_{88}$ cremation burial

Bibl.: Şovan 2005, 38, pl. 48B, 1.

7. thick-walled, coned-shaped glass beaker, decorated with four registers of ovals, sizes: $\mathrm{H}=12 \mathrm{~cm}$., discovered in $\mathrm{G}_{117}$ inhumation grave

Bibl.: Şovan 2005, 46, pl. 62, 13.

8. thin-walled transparent glass beaker (?), globed body and large opening, sizes: $\mathrm{H}=$ $4.4 \mathrm{~cm}$., discovered in $\mathrm{G}_{123}$ inhumation grave

Bibl.: Şovan 2005, 48, pl. 70, 49.

9. thick-walled, greenish glass beaker, cone-shaped, decorated with two large grooves, in between with three registers of hexagonal vertical facet cuts delimited by a row of small horizontal ovals, sizes: $\mathrm{H}=25.2 \mathrm{~cm}$., discovered in $\mathrm{G}_{175}$ inhumation grave

Bibl.: Şovan 2005, 62, pl. 95, 17.

10. thick-walled, greenish glass beaker, cone-shaped, decorated with four registers of ovals delimited in the upper register by a row of rare smaller ovals, placed horizontally, sizes: $\mathrm{H}$ $=14.4 \mathrm{~cm}$., discovered in $\mathrm{G}_{296}$ inhumation grave

Bibl.: Şovan 2005, 93, pl. 162, 15.

11. smashed thin-walled glass beaker (?), discovered in $\mathrm{G}_{297}$ inhumation grave

Bibl.: Şovan 2005, 95.

12. fragmentary glass beaker (?), melted, sizes: $H=4 \mathrm{~cm}$., discovered in $\mathrm{G}_{346}$ cremation grave

Bibl.: Şovan 2005, 107, pl. 189C, 1.

13. fragmentary glass beaker, decorated with ovals, circular base, sizes: $\mathrm{H}=1.4 \mathrm{~cm}$., discovered in $\mathrm{G}_{359}$ inhumation grave

Bibl.: Şovan 2005, 112, pl. 200, 8.

14. thick-walled greenish glass beaker, cone-shaped, decorated with four registers of vertical ovals, delimited in the upper part by a register of small rare horizontally placed ovals, sizes: $H=13 \mathrm{~cm}$., discovered in $\mathrm{G}_{369}$ inhumation grave 
Bibl.: Şovan 2005, 114, pl. 206A, 25.

15. thin-walled transparent glass beaker, cone-shaped, decorated with wide parallel horizontal grooves, sizes: $\mathrm{H}=19 \mathrm{~cm}$., discovered in $\mathrm{G}_{376}$ inhumation grave

Bibl.: Şovan 2005, 116, pl. 210, 13.

16. cream-coloured thick-walled glass beaker, decorated with four registers of ovals, rounded base, sizes: $\mathrm{H}=12.6 \mathrm{~cm}$., discovered in $\mathrm{G}_{405}$ inhumation grave

Bibl.: Şovan 2005, 122, pl. 225A, 2.

17. cream-coloured thick-walled glass beaker, decorated with five registers of ovals, delimited by grooves, sizes: $\mathrm{H}=15 \mathrm{~cm}$., discovered in $\mathrm{G}_{426}$ inhumation grave

Bibl.: Şovan 2005, 127, pl. 235C, 1.

18. thick-walled greenish glass beaker, cone-shaped, decorated with five registers of hexagonal and oval facet cuts, sizes: $\mathrm{H}=16 \mathrm{~cm}$., discovered in $\mathrm{G}_{450}$ inhumation grave

Bibl.: Şovan 2005, 131, pl. 245A, 12.

19. thin-walled glass beaker, truncated-cone shape, decorated with three wider grooves of which two more evident, sizes: $\mathrm{H}=18.8 \mathrm{~cm}$., discovered in $\mathrm{G}_{466}$ inhumation grave

Bibl.: Şovan 2005, 134, pl. 250C, 1.

IV. Miorcani (Dămieneşti commune, Botoşani county)

Iazul Mare or Izvorul Lupului, necropolis, systematic digs

20. transparent glass beaker (?), fragmentary, discovered in $\mathrm{G}_{115}$ inhumation grave

Bibl.: Ioniță 1977, R 49a, pl. 6.

21. thick, transparent, greenish glass beaker (?), decorated with large oval facet cuts, discovered in $\mathrm{G}_{133}$ inhumation grave

Bibl.: Ioniță 1977, R 51, pl. 2.

22. fragmentary glass beaker, cone-shaped, decorated with large ovals in the lower part and small ovals framed by fine grooves in the upper part, discovered in $\mathrm{G}_{144}$

Note: it may have exhibited an inscription in the upper part.

Bibl.: Gomolka-Fuchs 1999, 139, Abb. 7/2; Pánczél, Dobos 2007, 83-84, no. 40, pl. $\mathrm{V} / 40$.

V. Ripiceni (Ripiceni commune, Botoşani county)

Streleuca or Sterleuca, settlement, systematic digs

23. fragmentary (note) glass beakers (!?), unknown circumstances of discovery

Bibl.: Păunescu 1978, pp. 506-507.

VI. Tocileni (Stăuceni commune, Botoşani county)

Lutărie, necropolis, systematic digs

24. transparent glass beaker, fragmentary - upper part decorated with a row of ovals delimited by grooves under which appear the beginning letters of an inscription, of which is preserved only the first letter " $C$ ", discovered in $\mathrm{G}_{21}$

Bibl.: Gomolka-Fuchs 1999, 139, Abb. 7/1; Pánczél, Dobos 2007, 84, no. 41, pl. V/41.

VII. Todireni (Todireni commune, Botoşani county)

Malul Negru, settlement, systematic digs

25. glass beaker, cone-shaped, ended in a short circular foot, ornamented with ribs (bichrome or made from the same glass as the recipient?), applied in relief, sizes: $\mathrm{H}=14 \mathrm{~cm}$. discovered in damaged $\mathrm{G}_{1}$ or $\mathrm{G}_{2}$

Bibl.: Ioniță 1980, Abb. 2/12; Gomolka-Fuchs 1999, 139, Abb. 7/1; Pánczél, Dobos 2007, 84, no. 41, pl. V/41.

VIII. Truşeşti (Truşeşti commune, Botoşani county) 
Pe Cuha, settlement, systematic digs

26. glass (remark) beaker (?), unknown circumstances of find

Bibl.: Ioniță 1966, 207; Gomolka-Fuchs 1999, 141; Petrescu 2002, 258, no. 853d.

IX. Barcea (Barcea commune, Galați county)

Grădina de zarzavat, necropolis, systematic digs

27. iridescent glass beaker, cone-shaped, decorated with ribs applied in zigzag, bichrome, cream and blue, discovered in $\mathrm{G}_{114}$ inhumation grave

Bibl.: T,au, Nicu 1983, 421-428, fig. 8/6; Gomolka-Fuchs 1999, 136, Abb. 5/2 (and not $5 / 1$ as erroneously indicated by the illustration legend).

28. thin glass beaker, cone-shaped, ornamented with ribs applied in relief, bi-chrome (?), fragmentary - the lower part is missing, discovered in $\mathrm{G}_{137}$ inhumation grave

Bibl.: Gomolka-Fuchs 1999, 136, Abb. 5/2 (and not 5/1 as erroneously indicated by the illustration legend).

29.* cone-shaped beaker, with round lower part, ornamented with large ovals placed symmetrically on the body in four rows, discovered in $\mathrm{G}_{50}$ inhumation grave

Bibl.: Gomolka-Fuchs 1999, 136, Abb. 6/1.

30. thick glass beaker, cream-coloured, cone-shaped, provided with a short foot, above which four large ovals are placed in relief in the immediate vicinity, located symmetrically, thus faceting approximately half of the recipient height $(7.0 \times 4.5 \mathrm{~cm}$.), while the upper part in between appear small circles also symmetrical. The upper part is ornamented with two belts in relief, separated by a groove. The first is filled with small ovals separated by sets of parallel lines, the second, the upper, comprises an incised decoration in the shape of a fir (?) followed by the inscription $\pi i \varepsilon \zeta \dot{\eta} \sigma \eta \varsigma \chi \alpha \lambda \omega^{\prime} \varsigma \dot{\alpha} \varepsilon i$, sizes: $\mathrm{H}=14.6 \mathrm{~cm}$., D. opening $=11.3 \mathrm{~cm}$., D. base $=4.3$ $\mathrm{cm}$., discovered in $\mathrm{G}_{123}$ inhumation grave.

Bibl.: Țau, Nicu 1985, 165-166, fig. 1-2; Țau, Nicu 1986, 177-178, fig. 4/1; GomolkaFuchs 1999, 139, Abb. 7/5.

X. Cavadineşti (Cavadinești commune, Galați county)

Râpa Glodului, settlement, systematic digs

31. cream-coloured fragmentary glass beaker, iridescent - the lower part, the foot (note), unknown circumstances of discovery

Bibl.: Dragomir 1959, 466; Ursachi 1979, 171.

XI. Lunca (Jorăşti commune, Galați county)

Râpa cu Oale, necropolis, systematic digs

32. greenish glass beaker, semitransparent, iridescent and exfoliated, cylinder-shaped, large opening, slightly out-turned rim provided with an external groove, oval base, restored, exterior surface ornamented with four lenticular-oval registers, slightly concave, placed horizontally, sizes: $H=12.3 \mathrm{~cm}$., D. opening $=9 \mathrm{~cm}$., discovered in $\mathrm{G}_{21}$ inhumation grave

Bibl.: Dragomir 1996, 644-645, fig. 11/1; Dragomir 2001, 107, fig. 40/6.

33. greenish glass beaker, semitransparent, iridescent and exfoliated, cylinder-shaped, large opening, slightly out-turned rim provided with two horizontal incisions, oval base, restored, exterior surface ornamented with four lenticular-concave registers, placed horizontally, sizes: $\mathrm{H}=12 \mathrm{~cm}$., D. opening $=8 \mathrm{~cm}$., discovered in $\mathrm{G}_{35}$ inhumation grave

Bibl.: Dragomir 1996, 646-647, fig. 11/2; Dragomir 2001, 107, fig. 45/5.

\footnotetext{
*Within the exhibition "Antichitatea târzie în bazinul Prutului", recently opened, on 17.05.2009, at the "Vasile Pârvan" Museum from Bârlad, except for the recipient from $\mathrm{G}_{50}$, a beaker coming from the necropolis at Barcea, entirely preserved, belonging to type A (Eggers 230; Ekholm IIBc; Kowalk; Eketorpsglas 3/11; Straume I) is exhibited. The second piece, unique, was not taken into consideration herein.
} 
34. greenish glass beaker, semitransparent, iridescent and exfoliated, cylinder-shaped, large opened opening, slightly out-turned rim provided with two external grooves, rounded base, restored, exterior surface ornamented with four rows of lenticular cells placed horizontally, sizes: $\mathrm{H}=13 \mathrm{~cm}$., D. opening $=8.8 \mathrm{~cm}$., discovered the necropolis debris

Bibl.: Dragomir 1996, 647, fig. 11/3; Dragomir 2001, 107, fig. 47/6.

XII. Băiceni (Cucuteni commune, Iaşi county)

Silişte, settlement, systematic digs

35. fragmentary glass beaker (?) - the upper part preserves part of the ornament made of a row of small, horizontal ovals, unknown circumstances of discovery

Bibl.: Gomolka-Fuchs 1999, 131, Abb. $2 / 7$ (with reconstruction proposition).

36. fragmentary glass beaker (?) - the upper part preserves part of the ornament made of a row of circles and another row of ovals placed vertically and a fine groove, unknown circumstances of discovery

Bibl.: Gomolka-Fuchs 1999, 131, Abb. 2/7 (with reconstruction proposition).

XIII. Holboca (Holboca commune, Iaşi county)

La Moară, settlement (?), surface research

37. thick glass beaker (?), fragmentary, strongly iridescent, unknown circumstances of discovery

Bibl.: Zaharia, Dîmbovița, Zaharia 1970, 198, no. 44e.

XIV. Iaşi, (city, Iaşi county)

Fabrica de cărămizi, settlement, rescue excavations

38. fragmentary glass beaker, thick-walled and ornamented with hexagonal facet cuts (note), unknown circumstances of discovery

Bibl.: Ioniță 1972, p. 272, fig. 7/3.

XV. Iaşi, (city, Iaşi county)

Cartier Nicolina, settlement, rescue excavations

39. glass beaker (?), fragmentary, preserves part of the decoration made of circles and ovals, sizes: $\mathrm{L}=4.3 \mathrm{~cm}$., discovered in surface dwelling $\mathrm{A}_{9}$

Bibl.: Ioniță 1985, 43, fig. 11/4; Ioniță 1986, p. 76, fig. 16/3.

40. glass beaker (?), fragmentary, preserves part of the decoration made of ovals, sizes: $\mathrm{L}=4.6 \mathrm{~cm}$., discovered in surface dwelling $\mathrm{A}_{9}$

Bibl.: Ioniță 1985, 43, fig. 11/5; Ioniță 1986, p. 76, fig. 16/4.

41. glass beaker (?), fragmentary, preserves part of the decoration made of grooves, sizes: $\mathrm{L}=4.2 \mathrm{~cm}$., discovered in surface dwelling $\mathrm{A}_{9}$

Bibl.: Ioniță 1986, p. 76, fig. 16/2.

42. glass beaker (?), fragmentary, preserves part of the decoration made of hexagonal facet cuts, sizes: $\mathrm{L}=4.7 \mathrm{~cm}$, discovered in surface dwelling $\mathrm{A}_{14}$

Bibl.: Ioniţă 1985, p. 43, fig. 11/6; Ioniţă 1986, p. 76, fig. 16/5.

43. thick glass beaker, the lower part is cone-shaped, straight base and exhibits a groove above, still preserves part of the decoration made of hexagonal facet cuts, sizes: $\mathrm{H}=4.3 \mathrm{~cm}$., discovered in surface dwelling $\mathrm{B}_{3}$

Bibl.: Ioniță 1985, p. 43, fig. 11/7; Ioniță 1986, p. 76, fig. 16/6.

44. glass beaker (?), fragmentary, preserves part of the decoration made of large ovals, sizes: $\mathrm{L}=2.6 \mathrm{~cm}$., discovered in the surface dwelling $\mathrm{C}_{2}$

Bibl.: Ioniță 1986, p. 76, fig. 16/1.

XVI. Lețcani (Lețcani commune, Iaşi county) 
Vatra satului, necropolis, systematic digs

45. thin glass beaker, iridescent, cone-shaped, sizes: $H=12.4 \mathrm{~cm}$., discovered in $G_{23}$ inhumation grave

Bibl.: Bloşiu 1973, 111; Bloşiu 1975, 236, fig. 20/12; 41/9; 9.

XVII. Spinoasa (Erbiceni commune, Iaşi county)

Movila de la $N$ de halta C.F.R., necropolis (?), field walking

46. fragmentary glass beaker - lower part (note), unknown circumstances of discovery

Bibl.: Zaharia, Dîmbovița, Zaharia 1970, 218, no. 72c; Chirică, Tănăsachi 1984, 145, no. XXVI.3.C.

XVIII. Vânători (Popricani commune, Iaşi county)

Dealul Vultur, settlement (?), field walking

47. fragmentary glass beaker, decorated with ovals and two grooves near the opening (note), unknown circumstances of discovery

Bibl.: Zaharia, Dîmbovița, Zaharia 1970, 226, no. 85e; Chirică, Tănăsachi 1984, 325, no. LVIII.8.E.

XIX. Izvoarele (Dumbrava Roşie commune, Neamț county)

La Iaz, necropolis, systematic research

48. greenish glass beaker, iridescent, cone-shaped, ended in a small foot in the shape of a knob, decorated in the middle with three ellipses in relief rendering the sensation of facet cuts, sizes: $\mathrm{H}=12.4 \mathrm{~cm}$., $D$. opening $=10 \mathrm{~cm}$., discovered in $\mathrm{G}_{\mathrm{VIII}}$ inhumation grave

Bibl.: Vulpe 1957, 45-48, 300, fig. 319-320.

49. greenish glass beaker, cone-shaped, large opening and straight walls, ended in the lower part with a circular foot decorated with eight alveoli and two rows of eight facet cuts, discovered in $\mathrm{G}_{\mathrm{IX}}$ inhumation grave

Bibl.: Alexianu, Ellis 1995, 297, fig. 2/8; Petrescu 2002, 166; Gomolka-Fuchs 1999, 138, Abb. 6/7.

XX. Dolheştii Mari (Dolheşti commune, Suceava county)

La Todireasa, necropolis, systematic research

50. glass beaker (?), fragmentary (note), discovered in $\mathrm{G}_{23}$

Bibl.: Ignat 1980, 243; Ignat 1993, 321; Gomolka-Fuchs 1999, 141.

XXI. Moara Mică (Moara commune, Suceava county)

Putreda, necropolis, rescue excavations

51. coned greenish glass beaker with a reddish crust on the inside, thick and iridescent walls ornamented with a rib in relief under the edge and other ribs in relief slightly twisted starting from the beaker base and ascending to a height of $7 \mathrm{~cm}$., sizes: $\mathrm{H}=10 \mathrm{~cm}$., $\mathrm{D}=8 \mathrm{~cm}$., discovered in $\mathrm{G}_{1}$ inhumation grave

Note: the recipient has a base fracture, which may account for the existence of an ending foot (!?)

Bibl.: Emandi 1976, 381-382, 389-390, fig. 6/4; 9/1.

XXII. Bogdăneşti (Fălciu commune, Vaslui county)

Lutărie?, necropolis, rescue excavations

52. glass beaker, truncated- cone shape with tall and very thin walls, discovered in $G_{26}$ inhumation grave, disturbed

Bibl.: Palade 1973, 180, fig. 6/4; Coman 1980, 138, fig. 144/3.

XXIII. Bozia (Fălciu commune, Vaslui county)

Lutărie?, necropolis, rescue excavations 
53. iridescent glass beaker (?), white coloured, frosted Bibl.: Zaharia, Dîmbovița, Zaharia 1970, 341, no. 405c.

XXIV. Murgeni (Murgeni commune, Vaslui county)

(?), settlement, chance find (?)

54. fragmentary glass beaker - upper part, cone-shaped, large opening, the decoration preserves only two large rows of ovals and fragmentary, the third, in the upper part small horizontally placed ovals and a fine groove under the rim

Bibl.: Rau 1975, 480, Abb. 7; Straume 1987, 126, no. 143; Gomolka-Fuchs 1999, 140; Pánczél, Dobos 2007, 82, no. 29, pl. IV/29.

XXV. Obîrşeni-Lingurari (Voineşti commune, Vaslui county)

Dealul Coşărului, necropolis, systematic digs

55. fragmentary glass beaker (note) discovered in $\mathrm{G}_{7}$ inhumation grave

Bibl.: Mitrea 1969, 222.

XXVI. Pogoneşti (Iveşti commune, Vaslui county)

La Movilă, necropolis, systematic excavations

56. glass (?) beakers (!?) (note)

Bibl.: Mamalaucă 1997, pl. II/2; Mamalaucă 1998, 87.

XXVII. Poieneşti (Poieneşti commune, Vaslui county)

Dealul Teilor, necropolis, systematic excavations

57. glass beaker (?) decorated with semicircular lines (grooves? Glass threads?), located in the upper part

Bibl.: Gomolka-Fuchs 1999, 134, Abb. 4/8 (with reconstruction proposition).

XXVIII. Polocin (Iveşti commune, Vaslui county)

Izlaz, necropolis, systematic excavations

58. (a-b). well preserved glass beaker (note), discovered in $\mathrm{G}_{15}$ inhumation grave

Bibl.: Mamalaucă 2003, 245.

XXIX. Bârlad (city, Vaslui county)

Valea Seacă, necropolis, systematic excavations

59. fragmentary glass beaker (note), discovered in $\mathrm{G}_{4}$ cremation grave

Bibl.: Palade 2004, 87.

60. fragmentary glass beaker (note), discovered in $\mathrm{G}_{12}$ cremation grave

Bibl.: Palade 2004, 87.

61. fragmentary glass beaker (note), discovered in $\mathrm{G}_{18}$ cremation grave

Bibl.: Palade 2004, 88.

62. fragmentary glass beakers (!?) (note), discovered in $\mathrm{G}_{46}$ cremation grave

Bibl.: Palade 2004, 90.

63. fragmentary glass beaker, straight walls, coned-shaped, straight base, partial decoration - four fine parallel grooves in between with a row of ovals, respectively a fragmentary inscription (description upon drawing), discovered in $\mathrm{G}_{47 \mathrm{~A}}$ cremation grave

Bibl.: Palade 2004, 90, fig. 84/7.

64. yellow-brownish glass beaker, almost cylindrical, thin walls slightly bent outwards, spherical base; coloured glass, ornamented with four rows of ovals, discovered in $\mathrm{G}_{83}$ inhumation grave

Bibl.: Palade 2004, 114, fig. 165/2.

\footnotetext{
*Within the exhibition "Antichitatea târzie în bazinul Prutului", recently opened, on 17.05.2009, at the "Vasile Pârvan" Museum of Bârlad, two beakers from the Polocin necropolis are exhibited, both entirely preserved, novel, belonging to type A (Eggers 230; Ekholm IIBc; Kowalk; Eketorpsglas 3/11; Straume I). The second item was not considered herein.
} 
65. yellow-brownish fragmentary glass beaker, almost conical, thin recurved walls, spherical base, ornamented with five rows of ovals discovered in $\mathrm{G}_{84}$ inhumation grave

Bibl.: Palade 2004, 114, fig. 166/3.

66. yellowish glass beaker, greenish iridescent, cone-shaped, straight base, ornamented with hexagonal facet cuts, placed in four registers and a circular groove under the rim, discovered in $\mathrm{G}_{112}$ inhumation grave

Bibl.: Palade 2004, 116, fig. 177/2.

67. fragmentary glass beaker [although presented within the text as single exemplar (Palade 2004, 95), the illustration (fig. 277/1-4) shows four fragments, probably coming from different recipients most likely discovered within the same burial] straight walls whose decoration preserves two fine grooves (description upon drawing), discovered in $\mathrm{G}_{143}$ cremation grave

Bibl.: Palade 2004, 95, fig. 277/3.

68. fragmentary glass beaker - the upper part is missing, cone-shaped, straight walls (description upon drawing) discovered in $\mathrm{G}_{143}$ cremation grave

Bibl.: Palade 2004, 95, fig. 277/1.

69. fragmentary glass beaker (?), preserves part of the facet cut decoration (description upon drawing), discovered in $\mathrm{G}_{143}$ cremation grave

Bibl.: Palade 2004, 95, fig. 277/2.

70. fragmentary glass beaker (note), discovered in $\mathrm{G}_{160}$ cremation grave

Bibl.: Palade 2004, 96.

71. fragmentary glass beaker (note), discovered in $\mathrm{G}_{164}$ cremation grave

Bibl.: Palade 2004, 97.

72. glass beaker (note), discovered in $\mathrm{G}_{212}$ inhumation grave

Bibl.: Palade 2004, 120.

73. fragmentary glass beaker (note), discovered in $\mathrm{G}_{241}$ cremation grave

Bibl.: Palade 2004, 101.

74. fragmentary glass beaker (note), discovered in $\mathrm{G}_{257}$ cremation grave

Bibl.: Palade 2004, 102.

75. glass beaker (note), discovered in $\mathrm{G}_{279}$ inhumation grave

Bibl.: Palade 2004, 123.

76. fragmentary glass beaker (?) - upper part is missing, oval shape, straight base, ornamented with three rows of large distanced ovals (description upon drawing), discovered in $\mathrm{G}_{295}$ inhumation grave

Bibl.: Palade 2004, 125, fig. 206/16.

77. glass beaker (note), discovered in $\mathrm{G}_{307}$ inhumation grave

Bibl.: Palade 2004, 126.

78. glass beaker (note), discovered in $\mathrm{G}_{319}$ inhumation grave

Bibl.: Palade 2004, 127.

79. fragmentary glass beaker (note), discovered in $\mathrm{G}_{344}$ cremation grave

Bibl.: Palade 2004, 104-105.

80. fragmentary glass beaker (note), discovered in $\mathrm{G}_{363}$ inhumation grave

Bibl.: Palade 2004, 131.

81. fragmentary glass beaker (note), discovered in $\mathrm{G}_{373}$ cremation grave

Bibl.: Palade 2004, 105.

82. yellow-brownish glass beaker, almost cylindrical, thin, slightly recurved walls, spherical base ornamented with four rows of ovals, discovered in $\mathrm{G}_{380}$ inhumation grave

Bibl.: Palade 2004, 131, fig. 233/3. 
83. glass beaker (note, destroyed), discovered in $\mathrm{G}_{381}$ inhumation grave

Bibl.: Palade 2004, 132.

84. glass beaker (note, destroyed), discovered in $\mathrm{G}_{387}$ inhumation grave

Bibl.: Palade 2004, 132.

85. glass beaker, thick and faceted walls (decayed), discovered in $\mathrm{G}_{390}$ inhumation grave

Bibl.: Palade 2004, 133.

86. glass beaker (note, damaged), discovered in $\mathrm{G}_{409}$ inhumation grave

Bibl.: Palade 2004, 134.

87. fragmentary glass beaker (note), discovered in $\mathrm{G}_{414}$ cremation grave

Bibl.: Palade 2004, 107.

88. glass beaker (?), fragmentary - two fragments (the text mentions only one, yet the illustration shows two fragments) most likely coming from the same recipient (?), decoration that preserves at least two rows of inlaid ovals (description upon drawing), discovered in $\mathrm{G}_{450}$ cremation grave

Bibl.: Palade 2004, 109, fig. 151/13, 15.

89. glass beaker (note, damaged), discovered in $\mathrm{G}_{462}$ inhumation grave

Bibl.: Palade 2004, 137.

90. glass beaker (note, damaged), discovered in $\mathrm{G}_{486}$ inhumation grave

Bibl.: Palade 2004, 138.

91. fragmentary glass beaker (note), discovered in $\mathrm{G}_{492}$ cremation grave

Bibl.: Palade 2004, 111.

92. white glass beaker, transparent with violaceous iridescences on the exterior, comprising small air bubbles and dead fibres in the structure, cone-shaped, slim sharp body, thin-walled, out-turned rim with a slight groove inside and straight cut-edge, ornamented with two slightly deepened grooves made by polishing, placed one under the rim, the other, below, on the body, sizes: $\mathrm{H}=17.2 \mathrm{~cm}$., $\mathrm{D}=7.2 \mathrm{~cm}$., discovered in $\mathrm{G}_{501}$ inhumation grave

Bibl.: Palade 2004, 139, fig. 265/9.

93. glass beaker, truncated- cone shape, wide opening with straight rim and slightly rounded edge, narrow base, slightly concave, ornamented under the rim with a circular groove, slightly deepened, made by polishing, main decoration consisting of three rows of various sized inlaid ovals (description upon drawing), discovered in $\mathrm{G}_{506}$ inhumation grave

Bibl.: Palade 2004, 140, fig. 268/1.

94. yellowish glass beaker, transparent, with a few air bubbles in the structure, coneshaped, wide opening and straight rim, slightly rounded edge, narrow base, slightly concave, ornamented under the rim with three circular grooves, slightly deepened, made by polishing, of which two larger and the third finer and almost invisible, main decoration comprising four large ovals and four groups of three small dark- blue ovals, located on two levels; the upper register comprises two large ovals, placed symmetrically, face to face, inlaid by two groups of three smaller ovals, while the lower register exhibits similar arrangement, with the groups of smaller ovals positioned backwards, sizes: $\mathrm{H}=19.5 \mathrm{~cm}$., D. opening $=13.2 \mathrm{~cm}$., D. base $=2,6 \mathrm{~cm}$., discovered in $\mathrm{G}_{507}$ inhumation grave

Bibl.: Palade 2004, 141, fig. 269/4; Gomolka-Fuchs 1999, Abb. 5/4.

95. glass beaker (?) (note, damaged), discovered in $\mathrm{G}_{532}$ inhumation grave

Bibl.: Palade 2004, 145.

96. cone-shaped glass beaker, decorated in the central part with two rows of rather extended ovals, inlaid (description upon drawing), discovered in $\mathrm{G}_{541}$ inhumation grave

Bibl.: Palade 2004, 147, fig. 292/1. 
97. glass beaker (?), still preserving part of the facet cut decoration (description upon drawing), found within the layer

Bibl.: Palade 2004, 649, fig. 276/1.

98. fragmentary glass beaker - lower part still preserving part of the decoration: two rows of ovals (description upon drawing), found within the layer

Bibl.: Palade 2004, 649, fig. 276/2.

99. fragmentary beaker - the upper part is missing, footed, conical shape, thick straight walls, decorated with large ovals, upon reconstruction they seem to be four, faceting the recipient in four registers (description upon drawing), possible inscription in the upper register, found within the layer

Bibl.: Palade 2004, 649, fig. 276/3.

100. fragmentary beaker - centre part, cone shaped, thick, straight walls, decorated in the upper part by a fine groove, a row of small horizontal ovals, beneath with a row of larger ovals and beneath them hexagonal facet cuts (description upon drawing), discovered within the layer

Bibl.: Palade 2004, 649, fig. 276/4.

\section{BIBLIOGRAPHY}

Alexianu, Ellis 1995 - M. Alexianu, L. Ellis, La tombe IX de Izvoare, Dép. de Neamt, appartenant à la culture de Sântana de Mureş-Černjachov, AM 18, 295-302.

Barkoczi 1988 - L. Barkoczi, Pannonische Glasfunde in Ungarn, Budapest.

Băluță 1979 - C. L. Băluță, Considerații referitoare la răspândirea şi producerea sticlei în Dacia Superior, Apulum 17, 195-200.

Bârzu 1973 - L. Bârzu, Continuitatea populației autohtone în Transilvania în secolele IV-V (cimitirul 1 de la Bratei), Bucureşti.

Bobi 1985 - V. Bobi, Considerații preliminare asupra celor două necropole din secolul al IV-lea e.n. descoperite in Moldova de Jos, MA 9-11, 205-226.

Burger 1966 - A. Sz. Burger, The Late Roman Cemetery at Sâgvâr, ActaArchHung 18, 99-234.

Bloşiu 1973 - C. Bloşiu, Considerații preliminare asupra necropolei birituale din secolul al IV-lea e.n. de la Lețcani-Iaşi, CI 4, 93-125.

Bloşiu 1975 - C. Bloşiu, Necropola din secolul al IV-lea e.n. de la Lețcani (jud. Iaş̧i), AM 8, 203-280.

Bucovală 1968 - M. Bucovală, Vase antice de sticlă la Tomis, Constanța.

Chirică, Tănăsachi 1984 - V. Chirică, M. Tănăsachi, Repertoriul arheologic al județului Iaşi, I-II, Iaşi. Coman 1980 - Gh. Coman, Statornicie-continuitate. Repertoriul arheologic al județului Vaslui, Bucureşti. Constantinescu 1992 - E. M. Constantinescu, Rezultate ale cercetărilor arheologice de la Gherăseni Grindul Cremenea, jud. Buzău, privind obiectivele din secolul IV e.n., Carpica 23, 2, 193-208.

Culică 1974 - V. Culică, Un mormânt Sântana de Mureş-Cerneahov pe teritoriul municipiului Călăraşi, SCIVA 25, 3, 453-456.

Diaconu 1965 - Gh. Diaconu, Târgşor. Necropola din secolele III-IV e.n., Bucureşti.

Diaconu 1969 - Gh. Diaconu, Das Gräberfeld von Mogoşani (Kreis Dâmbovița), Dacia N.S. 13, 367-402.

Diaconu, Tzony, Constantinescu, Drâmbocianu 1977 - Gh. Diaconu, M. Tzony, M. Constantinescu, V. Drâmbocianu, L'ensemble archéologique de Pietroasele, Dacia N.S. 21, 199-220.

Dörner 1970 - E. Dörner, Cercetări şi săpături arheologice în județul Arad, MCA 9, 445-467.

Dragomir 1959 - I. T. Dragomir, Săpăturile arheologice de la Cavadineşti, MCA 6, 453-472.

Dragomir 1996 - I. T. Dragomir, Paharele de sticlă romane din necropola de tip Sântana de MureşCerneahov de la Lunca, județul Galați, Monografia arheologică a Moldovei de Sud (= Danubius 16), Galați, 641-660.

Dragomir 2001 - I. T. Dragomir, Necropola birituală Sântana de Mureş-Cerneahov de la Lunca, regiunea de sud a Moldovei (= Danubius 19), Galați.

Eggers 1951 - H. J. Eggers, Der römische Import im freien Germanien, Atlas der Urgeschichte, I, Hamburg. 
Ekholm 1965 - G. Ekholm, Als orientalisch angenommene Gläser Skandinaviens aus dem ersten bis aus dem sechsten Jahrhundert n.Chr., Antikvariskt Arkiv 26, 1-27.

Emandi 1976 - E. I. Emandi, Descoperiri arheologice din secolele IV-V e.n. în bazinul superior al Şomuzului Mare (jud. Suceava), SCIVA, 27, 3, 379-393.

Fedorov 1960 - G. B. Fedorov, Malaeštskij mogil'nik (pamjatnik Černjachovskoj kul'tury v bessejne reki Prut), MIA 82, 253-302.

Gaiu 1999 - C. Gaiu, Habitat şi manifestări rituale în secolul IV p. Chr. la Archiud, Revista Bistriţei 12-13, 267-316.

Gavrituchin 1999 - I. Gavrituchin, Hronologičeskie indicatory finala Černjachovskoj kul'tury. Tolstostennyye kubki so šlifovannoj i plastičeskoj ornamentaciej: koničeskie i s vydelennoj nožkoj (Eggers 236-238, Straume VI-IX), Sto let Černjachovskoj kul'ture, Kiev, 48-86.

Gavrituchin 2000 - I. Gavrituchin, Final tradicii kul'tur rimskogo vremeni v Vostočnoj Evrope, Die spätrömische Kaiserzeit und die frühe Völkerwanderungszeit in Mittel- und Osteuropa, Lodz, 261-320.

Godłowski 1970 - K. Godłowski, The Chronology of the Late Roman and Early Migration Period in Central Europe, Prace Archeologiczne (Kraków), 11.

Godłowski 1992 - K. Godłowski, Die Chronologie der jüngeren und späten Kaiserzeit in den Gebieten südlich der Sudeten und Karpaten, Probleme der relativen und absoluten Chronologie ab Laténezeit bis zum Frühmittelalter, Kraków, 23-54.

Gomolka-Fuchs 1999 - G. Gomolka-Fuchs, Gläser der Sîntana de Mureş- Černjachov-Kultur aus Rumäniein und der Republik Moldavien, Die Sîntana de Mureş-Černjachov-Kultur, Bonn, 129-141.

Harden 1970 - D. B. Harden, Ancient Glass, II: Roman, The Archaeological Journal, CXXVI, Londra, 1969 (1970). Ignat 1980 - M. Ignat, Cercetările arheologice de la Dolheştii Mari, MCA 14, 243-245.

Ignat 1993 - M. Ignat, Necropola de la Dolheştii Mari, jud. Suceava, MCA, Ploieşti, 1983 (Bucureşti, 1993), 321223.

Ioniță 1972 - I. Ioniță, Aşezarea de tip Sântana de Mureş-Cerneahov de la Iaşi - Fabrica de cărămizi, AM 7, 267-306.

Ioniță 1977 - I. Ioniță, La nécropole du IV siècle de n.è. a Miorcani, Inventaria Archaeologica 8 (R 42 - R 51), Bucureşti. Ioniță 1980 - I. Ioniță, Die Römer-Daker und die Wandervölker, Die Römer-Daker und die Wandervölker im donauländischen Karpatenraum im 4. Jahrhundert, Die Völker an der mittleren und unteren Donau im fünften und sechsten Jahrhundert (I. Ioniță ), Wien, 123-129.

Ioniță 1982 - I. Ioniță, Din istoria şi civilizaţia dacilor liberi, Iaşi.

Ioniță 1985 - I. Ioniță, Importante descoperiri arheologice din perioada de formare a poporului Român în aşezarea de la Iaşi - Nicolina, AM 10, 33-49.

Ioniță 1986 - I. Ioniță, Mărturii milenare în vatra Iaşilor, Fortus, Iaşi, 63-84.

Ioniță 1986a - I. Ioniță, Chronologie der Sântana de Mureş-Černjachov-Kultur (I), Peregrinatio Gothika (AB VII), Lodz, 295-351.

Ioniță, Straume 1993 - I. Ioniță, E. Straume, Gläser mit Facettenschliff aus skandinavischen Gräben des 4. und 5. Jahrhunderts n. Chr., Oslo, 1987, Germania 71, 1, 266-267.

Ioniță 1994-1995 - I. Ioniță, Eine Glasschale mit eingeritztem Wabenmuster und Facettenschliff von Iacobeni (Kr. Iaşi), Dacia N.S. 38-39, 151-162.

Ioniță 2000-2001 — I. Ioniță, Vase de sticlă romane la dacii liberi (secolele II-III d. Hr.), AM 23-24, 219247.

Isings 1951 - Roman Glass from Dated Finds, Croningen-Djacarta.

Keller 1971 - E. Keller, Die spätrömischen Grabfunde in Südbayern, München.

Kovács 1912 - I. Kovács, Amarosszentannai népvándorláskori temetö, Dolgozatok az Erdély Nemzeti Múzeum Érem-és Régiségtárából III, 250-342.

Kropotin 1970 - V. V. Kropotin, Rimskie importnye izdelija v vostočnoj Evrope (II v. Do n.e. - V v.n.e.) (= Arheologija SSSR, D 1-27).

Levinschi 1997 - A. Levinschi, Despre un grup de necropole ale culturii Sântana de Mureş Černjachov din interfluviul Nistru-Prut, Tyragetia 4-5, 117-130. 
Lund-Hansen 1987 - U. Lund Hansen, Römischer Import im Norden. Warenaustausch zwischen dem römischen Reich und den freien Germanien während der Kaiserzeit unter besonderer Berücksichtigung Nordeuropas. Nordiske Fortidsminder, København.

Lungu, Chera-Mărgineanu 1982 - V. Lungu, C. Chera-Mărgineanu, Contribuții la cunoaşterea unei necropole creştine a Tomisului (I), Pontica 15, 175-199.

Magomedov 1999 - B. V. Magomedov, Černjachovskij mogil’nik Kurniki na Južnom Buge, Stratum plus 4, Sankt-Petersburg, 102-120.

Mamalaucă 1997 - M. Mamalaucă, Săpăturile arheologice în necropola de secol IV p. Chr. de la Pogoneşti-Iveşti, Carpica 26, 147-166.

Mamalaucă 1998 - M. Mamalaucă, Pogoneşti, com. Iveşti, jud. Vaslui, CCA, 87.

Mamalaucă 2003 - M. Mamalaucă, Polocin, com. Iveşti, jud. Vaslui, CCA, 245.

Mitrea 1969 - I. Mitrea, Necropola din sec. IV e.n. de la Obîrşeni-Voineşti, Carpica 2, 219-232.

Mitrea 1979 - I. Mitrea, Descoperiri arheologice din secolul al IV-lea în comuna Dămieneşti, județul Bacău, Carpica 11, 171-180.

Mitrea 1986 - I. Mitrea, Cercetări arheologice în aşezarea din secolele II-V e.n. de la Cârligi, comuna Filipeşti, jud. Bacău, MCA (Vaslui, 1982), Bucureşti, 1986, 135-144.

Mitrea, Preda 1966 - B. Mitrea, C. Preda, Necropolele din secolul al IV-lea e.n. în Muntenia, Bucureşti. Muşețeanu 1986 - C. Muşețeanu, Necropola din secolul al IV-lea e.n. de la Copuzu, CCDJ II, 209220.

Näsman 1984 - U. Näsman, Glas och handel i senromersk tid och folkvandringstid. En studie kring glas grån Eketorp-II, Öland Sverige, Uppsala.

Palade 1973 - V. Palade, Săpăturile arheologice de la Bogdăneşti-Fălciu, jud. Vaslui (1967-1968), MCA 10, 170-188.

Palade 2004 - V. Palade, Aşezarea şi necropola de la Bârlad-Valea Seacă, Bucureşti.

Păunescu 1978 - Al. Păunescu, Contribuții privind realitățile din nordul Moldovei în secolul al IV-lea e.n. în lumina cercetărilor de la Ripiceni, SCIVA 29, 4, 505-517.

Pánczél, Dobos 2007 - S. Pánczél, A. Dobos, Facet Cut Glass Vessels of the Late $3^{\text {rd }}$ to $5^{\text {th }}$ century AD. Analysis of finds from north Danubian Romania, Funerary offerings and votive depositions in Europe's $1^{\text {st }}$ millennium AD. Cultural artefacts and local identities (ed. C. Cosma), Cluj-Napoca, 67-97.

Petrescu 2002 - Fl. Petrescu, Repertoriul monumentelor arheologice de tip Sântana de Mureş_Cerneahov de pe teritoriul României, Bucureşti.

Preda 1980 - C. Preda, Callatis. Necropola romano-bizantină, Bucureşti.

Rafalovič 1986 - I. A. Rafalovič, Dančeny. Mogil'nik Černjahovskoj kul’tury, Chişinău.

Rau 1972 - G. Rau, Körpergräber mit Glasbeigaben des 4. nachchristlichen Jahrhunderts im OderWeichsel-Raum, APA 3, 109-214.

Rau 1975 - G. Rau, Spätantike Glasfunde im Karpatenraum, Zeitschr. Ostforsch 24, 464-485.

Rikman 1972 - E. A. Rikman, Vapros datirovki importnych veščj v pamjatnikach plemen Černjachovkoj kul'tury Dnestrovsko-Prutskogo meždureč’ja, Sovetskaja Archeologija 3 84-101.

Ščukin 2005 - M. B. Ščukin, Gotskij put', Sankt-Petersburg.

Sorokina 1962 - N. P. Sorokina, Stekljannyj sosud iz nižnego Podnestrovja, Krat. Soob. Inst. Arch., Moskva 89, 210-236.

Straume 1987 - E. Straume, Gläser mit Facettenschliff aus skandinavischen Gräben des 4. und 5. Jahrhunderts n. Chr., Oslo.

Symonovič 1960 - E. A. Symonovič, Raskopki mogilnika u ovčarni sovchoza Pridneprovskogo na nižnem Dnepre, MIA 82.

Symonovič 1964 - E. A. Symonovič, Stekljannye kubki iz Žuravki, Krat. Soob. Inst. Arch. Moskova, 102. Symonovič 1966 - E. A. Symonovič, Steckljanny kubok s nadpis'ju is-pod Odessy, Vestnik Drevnej Istorii, Moskva, 1.

Şovan 2005 - O. L. Şovan, Necropola de tip Sântana de Mureş-Cerneahov de la Mihălăşeni (județul Botoşani), Târgovişte. 
Tejral 1987 - J. Tejral, Zur Chronologie und Deutung der südöstlichen Kulturelemente in der frühen Völkerwanderungszeit Mitteleuropas, Die Völkerwanderungszeit im Karpatenbecken. Anzeiger der Germanischen Nationalmuseums, Nürnberg, 11-46.

Tejral 1992 - J. Tejral, Einige Bemerkungen zur Chronologie der späten römischen Kaiserzeit in Mitteleuropa. Probleme der relativen und absoluten Chronologie ab Latènezeit bis zum Frühmittelalter, Kraków, 227-248.

Țau, Nicu 1983 - S. Țau, M. Nicu, Necropola din secolul al IV-lea e.n. de la Barcea (jud. Galați), MCA, Bucureşti, 415-428.

Țau, Nicu 1985 - S. Țau, M. Nicu, Ein Beschrifteter Glasbecher aus der Nekropole von Barcea-Tecuci (4 Jahrhundert u. Z.), Dacia N.S. 29, 1-2, 165-166.

Țau, Nicu 1986 - S. Țau, M. Nicu, Săpăturile arheologice din necropola birituală din secolul al IV-lea e.n. de la Barcea, jud. Galați, MCA, Bucureşti, 172-179.

Ursachi 1979 - V. Ursachi, Elemente şi influențe romane la est de Carpați în secolele II-III e.n., Hierasus 1, 147-185.

Vornic 2006 - V. Vornic, Aşezarea şi necropola de tip Sântana de Mureş-Cerneahov de la Budeşti, Chişinău. Vulpe 1957 - R. Vulpe, Izvoare. Săpăturile din 1936-1948, Bucureşti.

Zaharia, Dîmbovița, Zaharia 1970 - N. Zaharia, M. Petrescu-Dîmbovița, Em,. Zaharia, Așezări din Moldova. De la paleolitic până în secolul al XVIII-lea, Bucureşti.

\begin{tabular}{|l|l|c|c|}
\hline \multicolumn{1}{|c|}{ No. } & \multicolumn{1}{c|}{ Find spot } & Site type & No. of items \\
\hline I & Călugăreni (BC) & necropolis & 1 \\
\hline II & Cârligi (BC) & settlement & 1 \\
\hline III & Mihălăşeni (BT) & necropolis & 17 \\
\hline IV & Miorcani (BT) & necropolis & 3 \\
\hline V & Ripiceni (BT) & settlement & 1 \\
\hline VI & Tocileni (BT) & necropolis & 1 \\
\hline VII & Todireni (BT) & necropolis & 1 \\
\hline VIII & Truşeşti (BT) & settlement & 1 \\
\hline IX & Barcea (GL) & necropolis & 4 \\
\hline X & Cavadineşti (GL) & settlement & 1 \\
\hline XI & Lunca (GL) & necropolis & 3 \\
\hline XII & Băiceni (IS) & settlement & 2 \\
\hline XIII & Holboca (IS) & settlement & 1 \\
\hline XIV & Fabrica de cărămizi (IS) & settlement & 1 \\
\hline XV & Cartier Nicolina (IS) & settlement & 6 \\
\hline XVI & Lețcani (IS) & necropolis & 1 \\
\hline XVII & Spinoasa (IS) & necropolis & 1 \\
\hline XVIII & Vânători (IS) & settlement & 1 \\
\hline XIX & Izvoarele (NT) & necropolis & 2 \\
\hline XX & Dolheştii Mari (SV) & necropolis & 1 \\
\hline XXI & Moara Mică (SV) & necropolis & 1 \\
\hline XXII & Bogdăneşti (VS) & necropolis & 1 \\
\hline XXIII & Bozia (VS) & necropolis & 1 \\
\hline XXIV & Murgeni (VS) & nettlement & 1 \\
\hline XXV & Obârşeni-Lingurari (VS) & necropolis & 1 \\
\hline XXVI & Pogoneşti (VS) & necropolis & 1 \\
\hline XXVII & Poieneşti (VS) & necropolis & 1 \\
\hline XXVIII & Polocin (VS) & necropolis & 42 \\
\hline XXIX & Valea Seacă (VS) & 10 & 100 \\
\hline & Total & nelis & 1 \\
\hline & Fig. 3. Glass beakers & 1 \\
\hline
\end{tabular}

Fig. 3. Glass beakers discovered in Moldova 


\begin{tabular}{|c|c|c|c|c|c|}
\hline \multirow[t]{2}{*}{ No. } & \multicolumn{2}{|c|}{ Necropolis } & \multirow[t]{2}{*}{ Settlement } & \multirow[t]{2}{*}{ No data } & \multirow[t]{2}{*}{ Remarks } \\
\hline & Inhumation & Cremation & & & \\
\hline 1 & 1 & 5 & 2 & 22 (necropolis) & \\
\hline 2 & 3 & 6 & 23 & 24 (necropolis) & \\
\hline 3 & 4 & 12 & 26 & 25 (necropolis) & \\
\hline 4 & 7 & 59 & 31 & 34 (necropolis) & Debris \\
\hline 5 & 8 & 60 & 35 & 46 (necropolis) & \\
\hline 6 & 9 & 61 & 36 & 50 (necropolis) & \\
\hline 7 & 10 & 62 & 37 & 53 (necropolis & \\
\hline 8 & 11 & 63 & 38 & 56 (necropolis) & \\
\hline 9 & 13 & 67 & 39 & 57 (necropolis) & \\
\hline 10 & 14 & 68 & 40 & 58 (necropolis) & \\
\hline 11 & 15 & 69 & 41 & 97 (necropolis) & layer \\
\hline 12 & 16 & 70 & 42 & 98 (necropolis) & layer \\
\hline 13 & 17 & 71 & 43 & 99 (necropolis) & layer \\
\hline 14 & 18 & 73 & 44 & 100 (necropolis & layer \\
\hline 15 & 19 & 74 & 47 & & \\
\hline 16 & 20 & 79 & 54 & & \\
\hline 17 & 21 & 81 & & & \\
\hline 18 & 27 & 87 & & & \\
\hline 19 & 28 & 88 & & & \\
\hline 20 & 29 & 91 & & & \\
\hline 21 & 30 & & & & \\
\hline 22 & 32 & & & & \\
\hline 23 & 33 & & & & \\
\hline 24 & 45 & & & & \\
\hline 25 & 48 & & & & \\
\hline 26 & 49 & & & & \\
\hline 27 & 51 & & & & \\
\hline 28 & 52 & & & & \\
\hline 29 & 55 & & & & \\
\hline 30 & 64 & & & & \\
\hline 31 & 65 & & & & \\
\hline 32 & 66 & & & & \\
\hline 33 & 72 & & & & \\
\hline 34 & 75 & & & & \\
\hline 35 & 76 & & & & \\
\hline 36 & 77 & & & & \\
\hline 37 & 78 & & & & \\
\hline 38 & 80 & & & & \\
\hline 39 & 82 & & & & \\
\hline 40 & 83 & & & & \\
\hline 41 & 84 & & & & \\
\hline 42 & 85 & & & & \\
\hline 43 & 86 & & & & \\
\hline 44 & 89 & & & & \\
\hline 45 & 90 & & & & \\
\hline 46 & 92 & & & & \\
\hline 47 & 93 & & & & \\
\hline
\end{tabular}




\begin{tabular}{|l|l|l|l|l|l|}
\hline 48 & 94 & & & & \\
\hline 49 & 95 & & & & \\
\hline 50 & 96 & & & & \\
\hline
\end{tabular}

Fig. 4. Distribution of glassware upon site categories

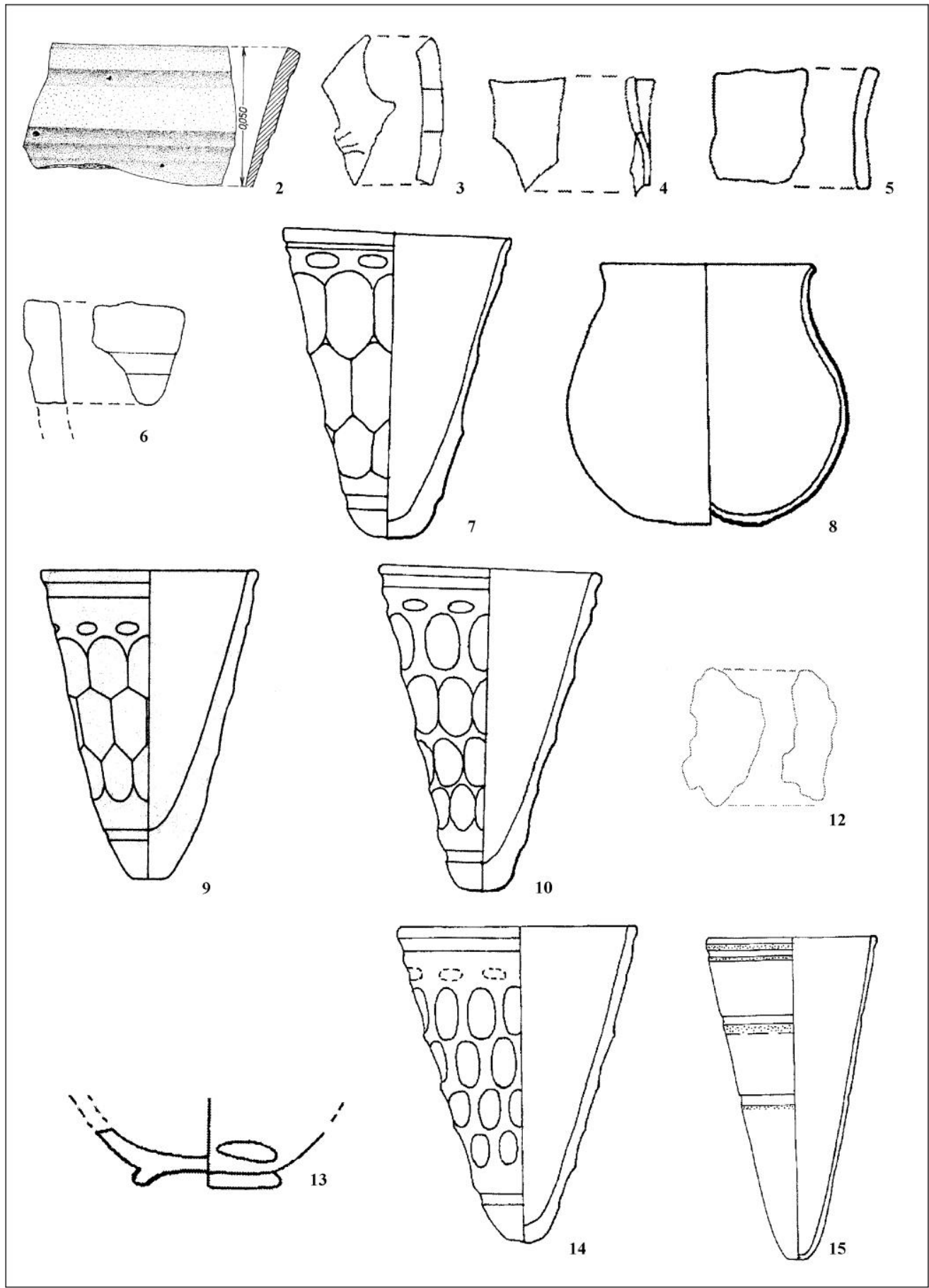

Fig. 5. Glass beakers 


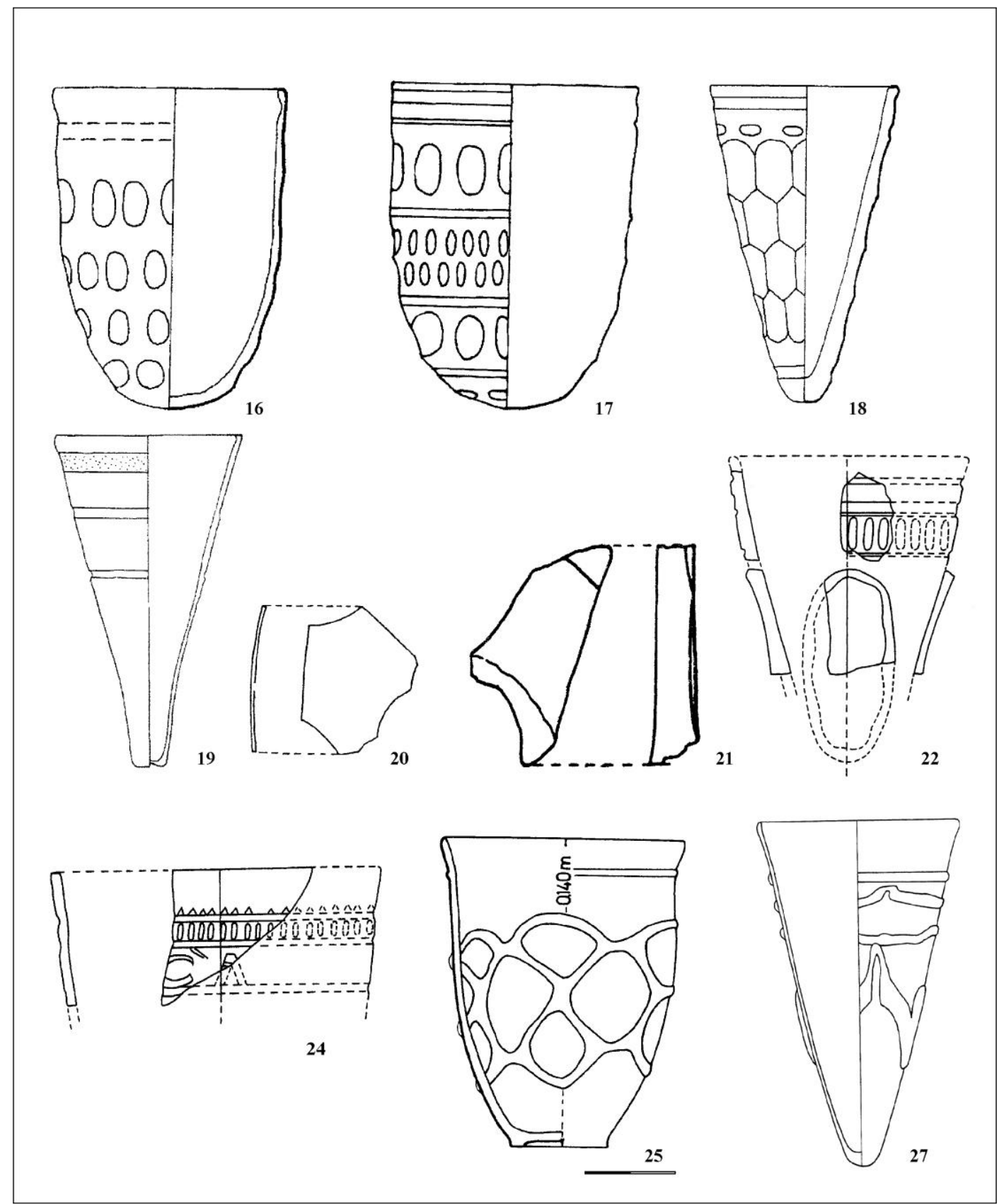

Fig. 6. Glass beakers 


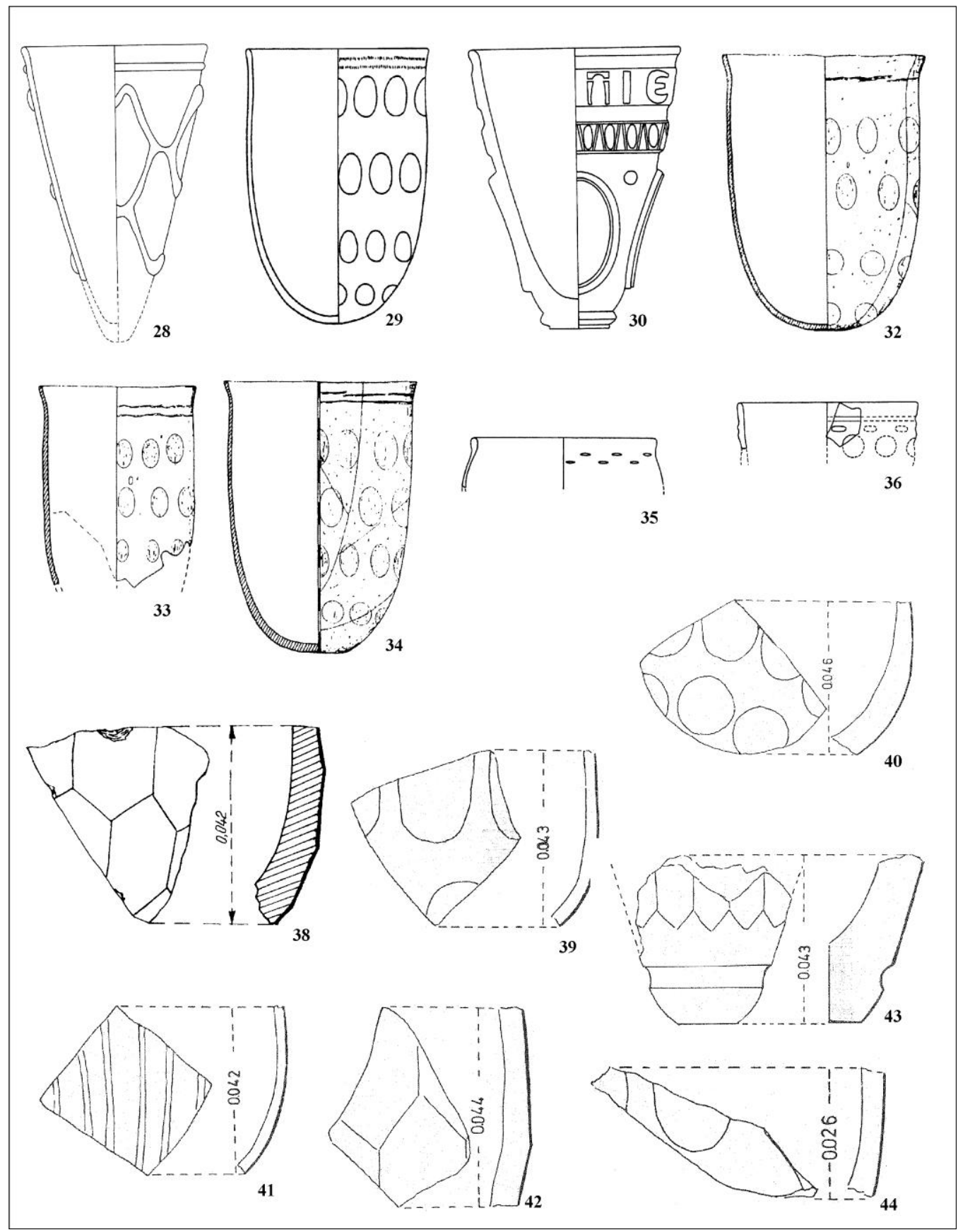

Fig. 7. Glass beakers 


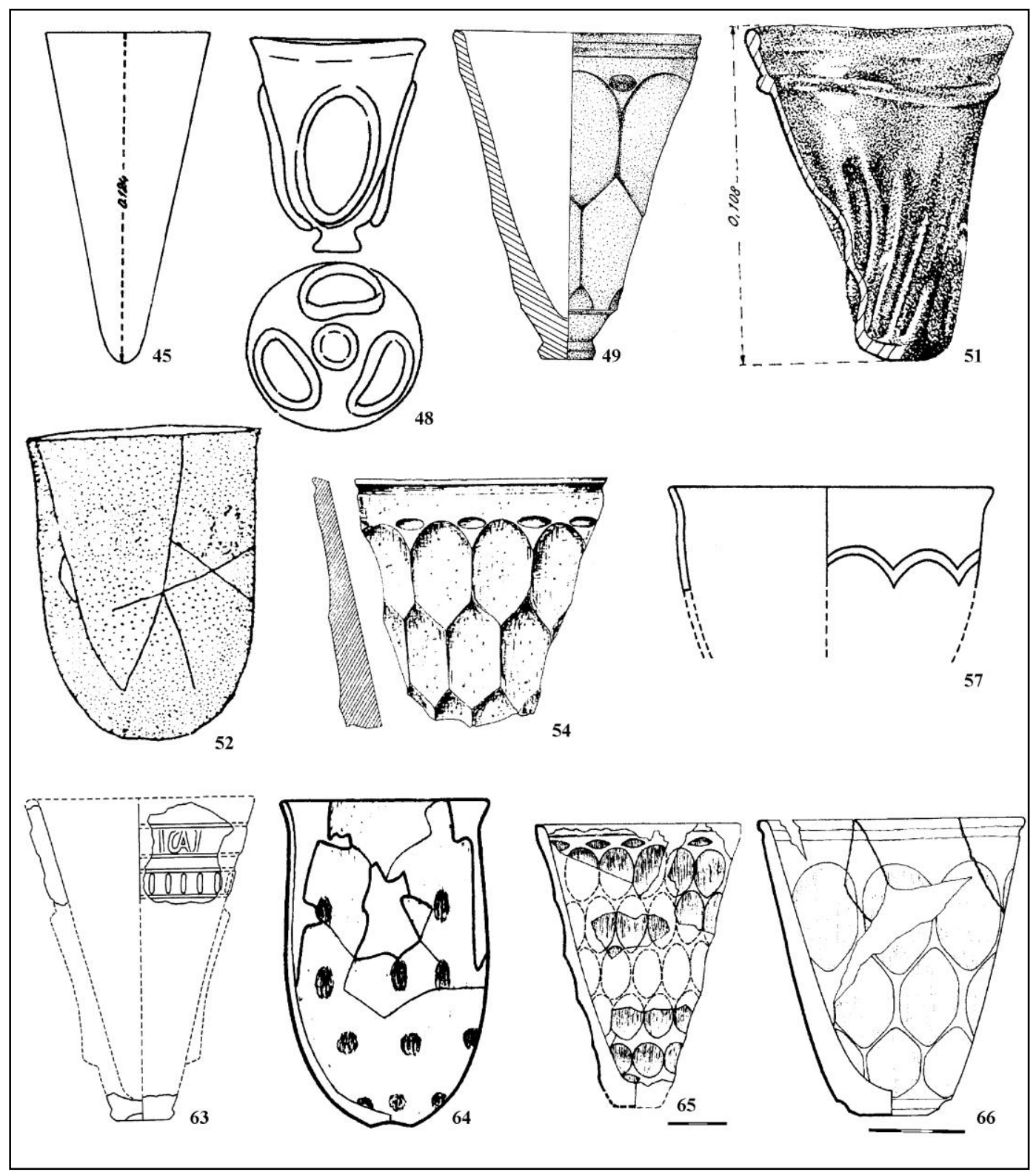

Fig. 8. Glass beakers 


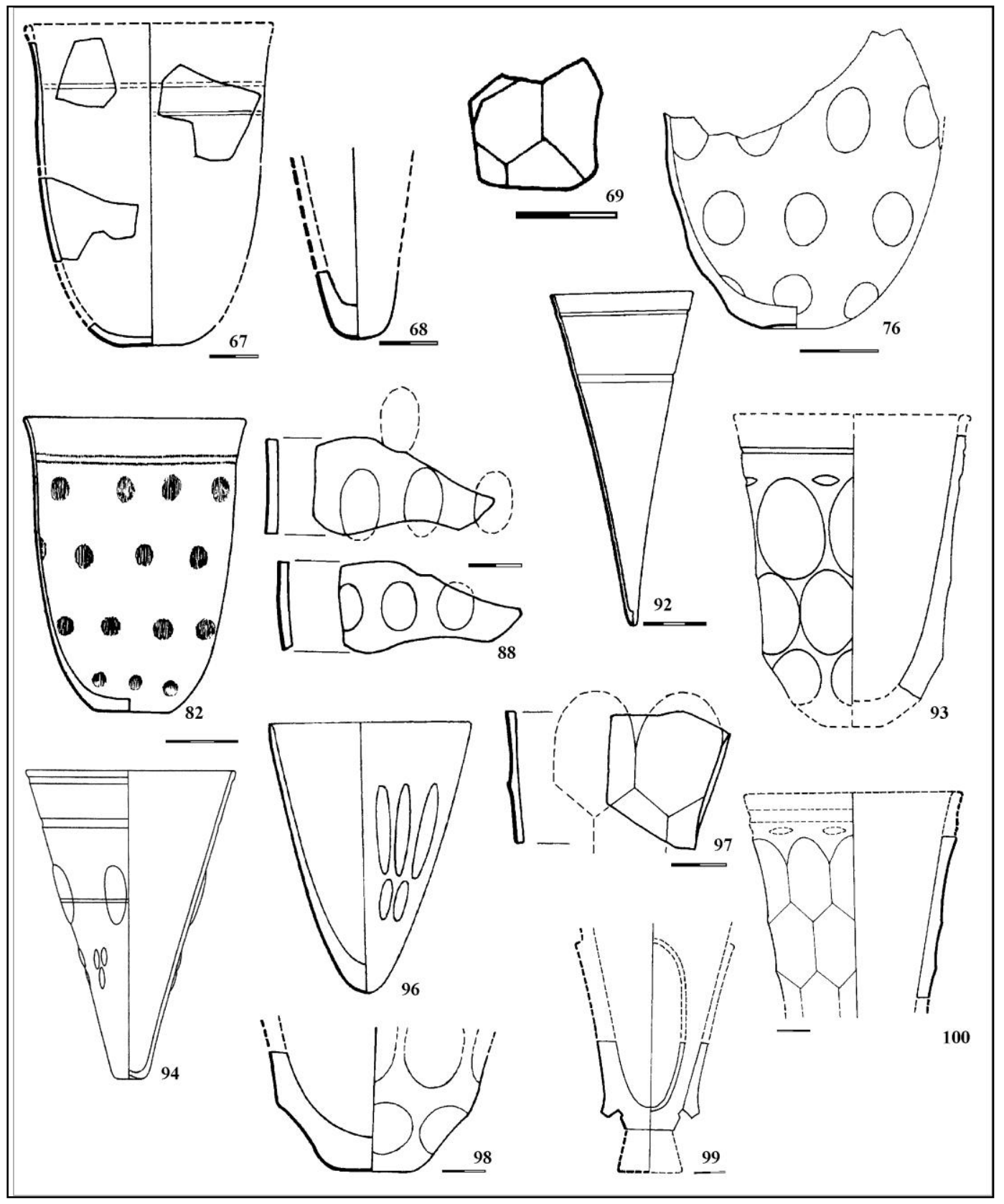

Fig. 9. Glass beakers 


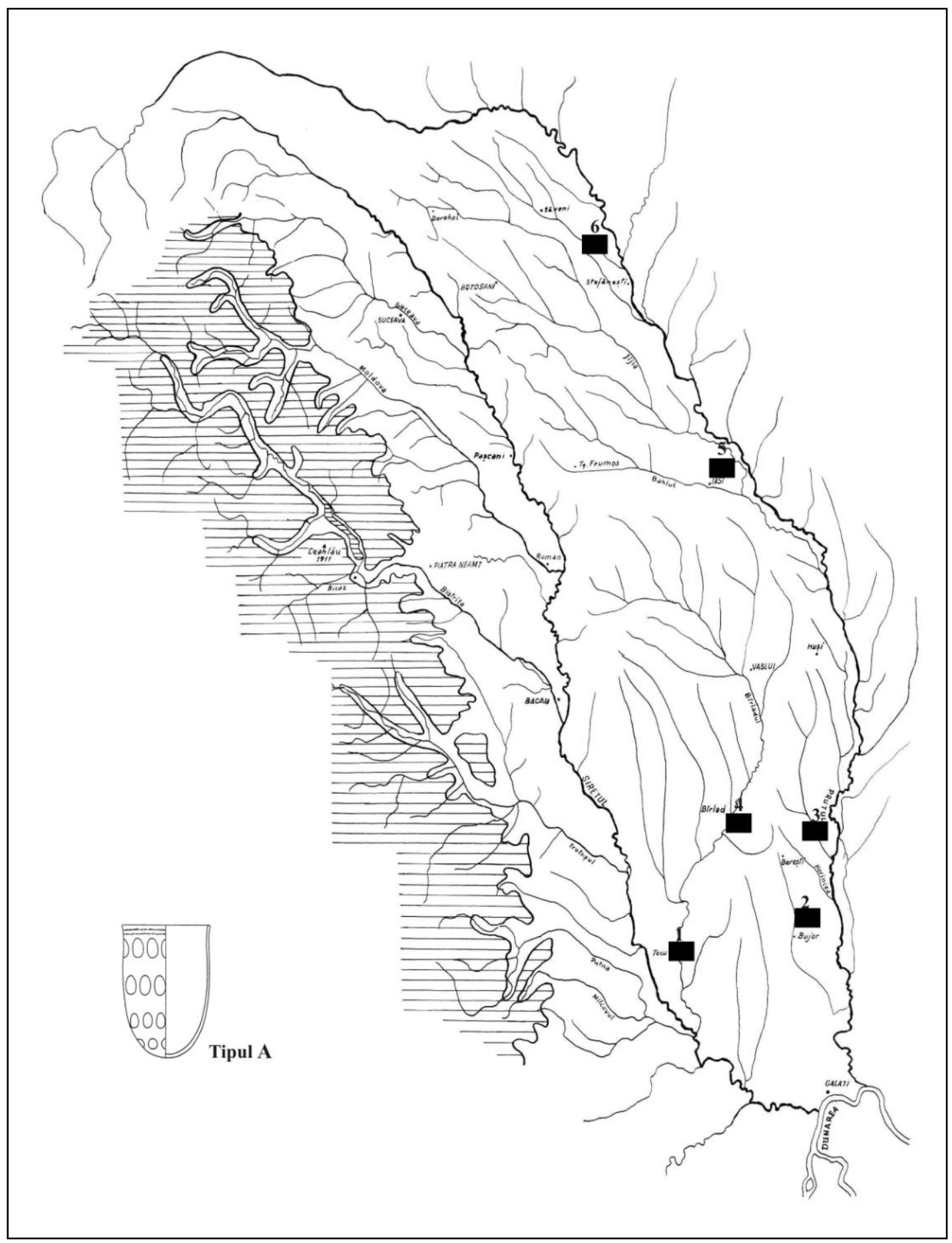

Fig. 10. Distribution of A-type beakers. 1. Barcea; 2. Lunca; 3. Bogdăneşti; 4. Bârlad - Valea Sacă; 5. Iaşi-Nicolina; 6. Mihălăşeni 


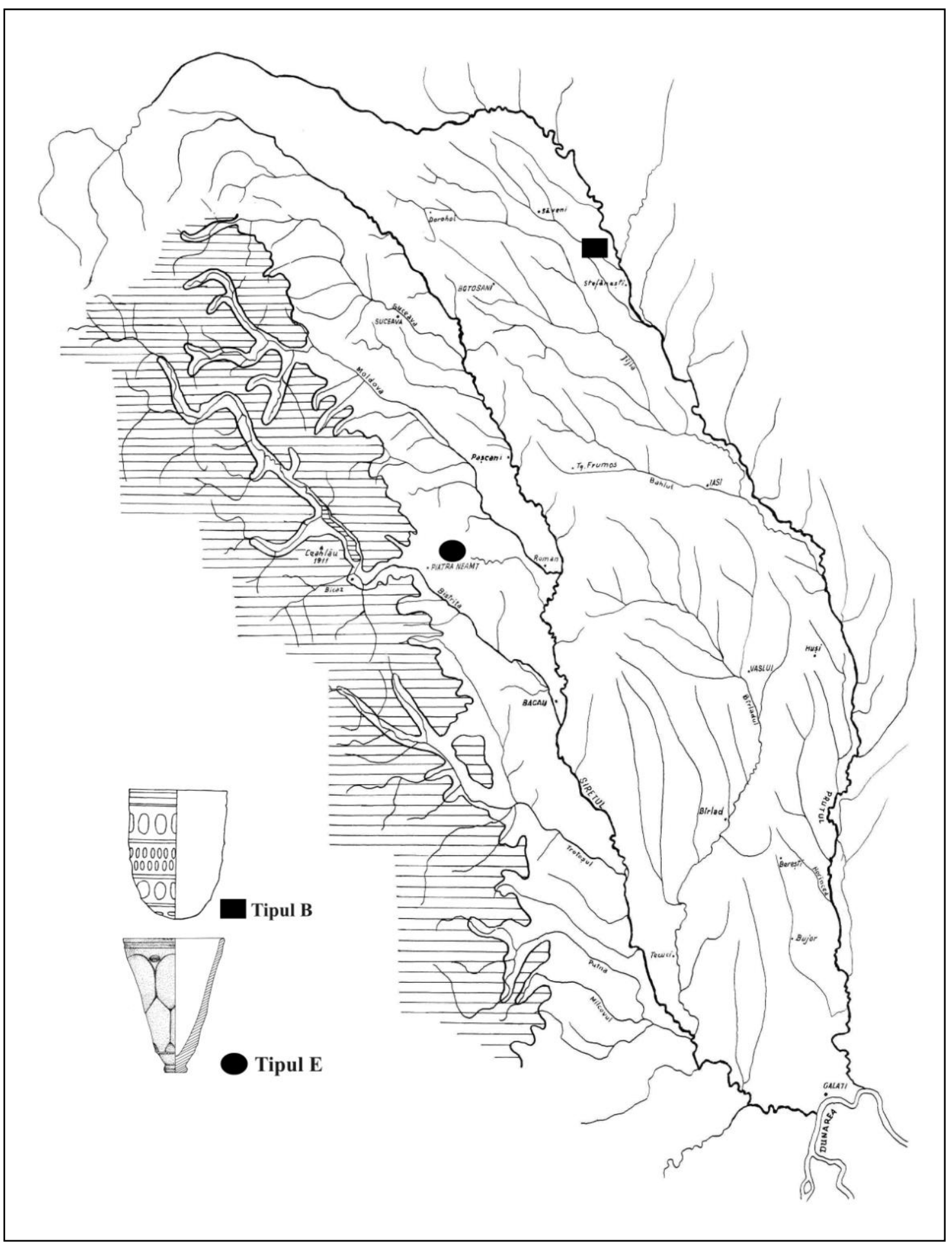

Fig. 11. Distribution of B-type (Mihălăşeni $\mathrm{G}_{426}$ ) and E-type beakers (Izvoare $\mathrm{G}_{9}$ ) 


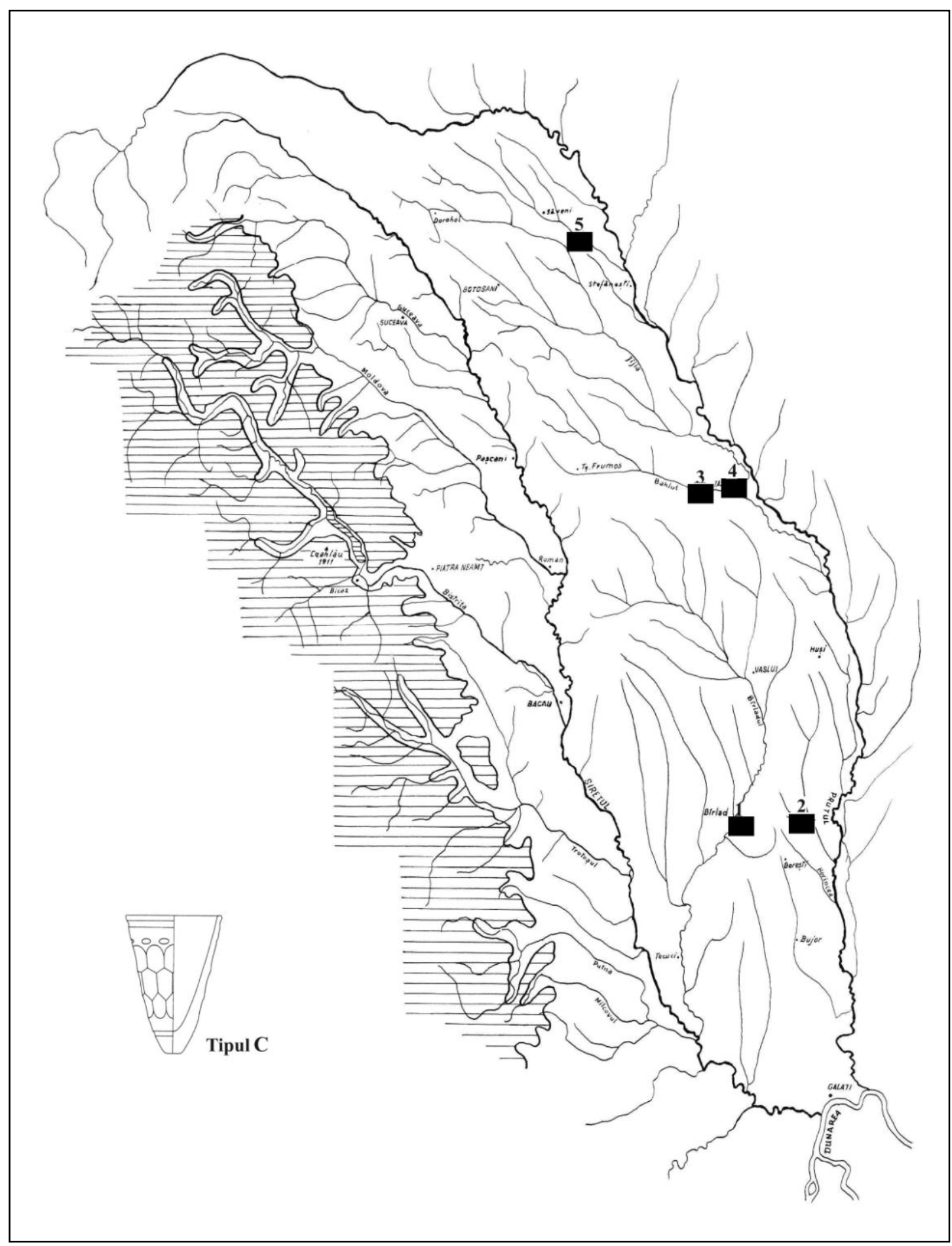

Fig. 12. Distribution of C-type beakers. 1. Bârlad - Valea Sacă; 2. Murgeni; 3. Iaşi-Nicolina; 4. IaşiFabrica de Cărămizi; 5. Mihălăşeni 


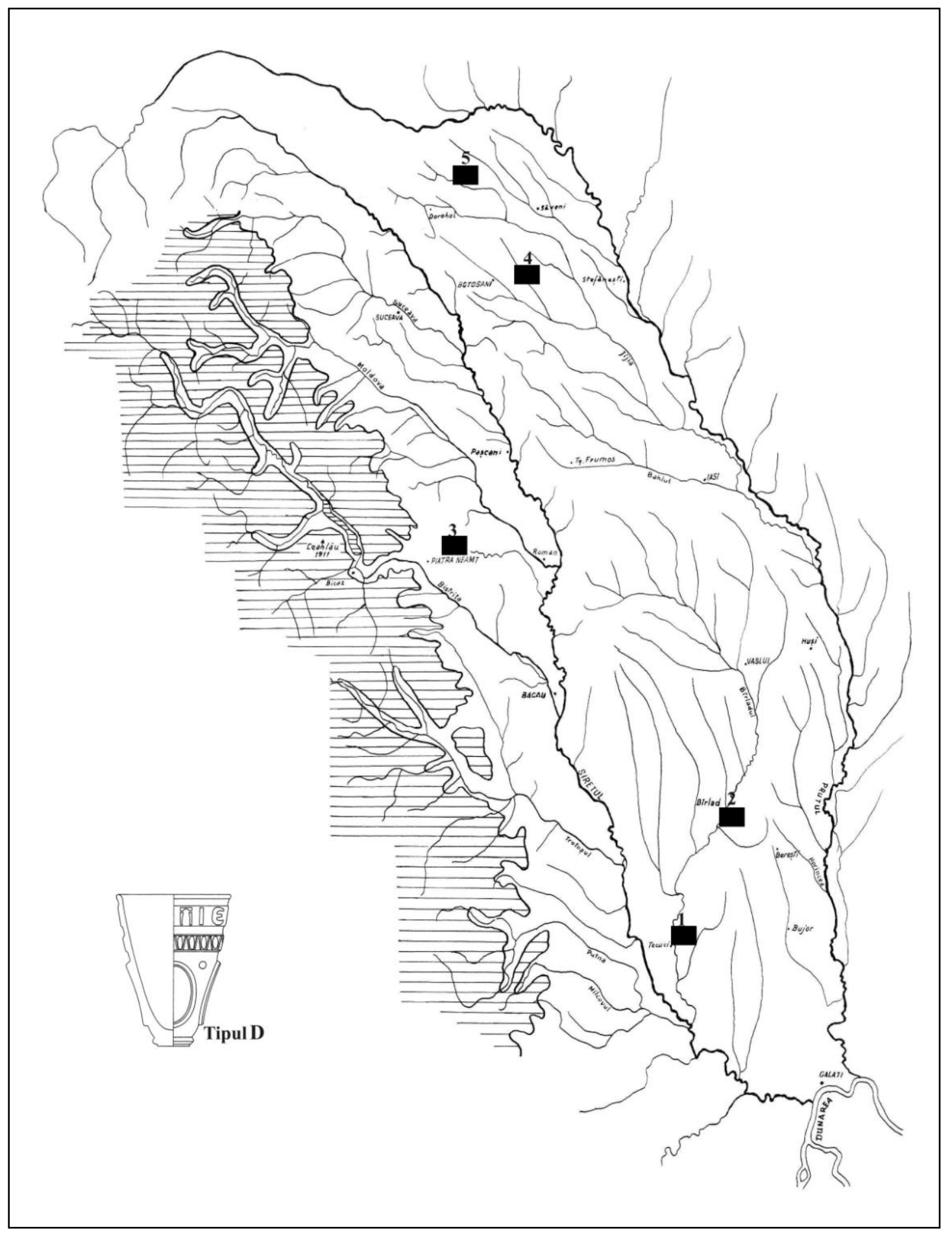

Fig. 13. Distribution of D-type beakers. 1. Barcea; 2. Bârlad - Valea Sacă; 3. Izvoare; 4. Tocileni; 5. Miorcani 


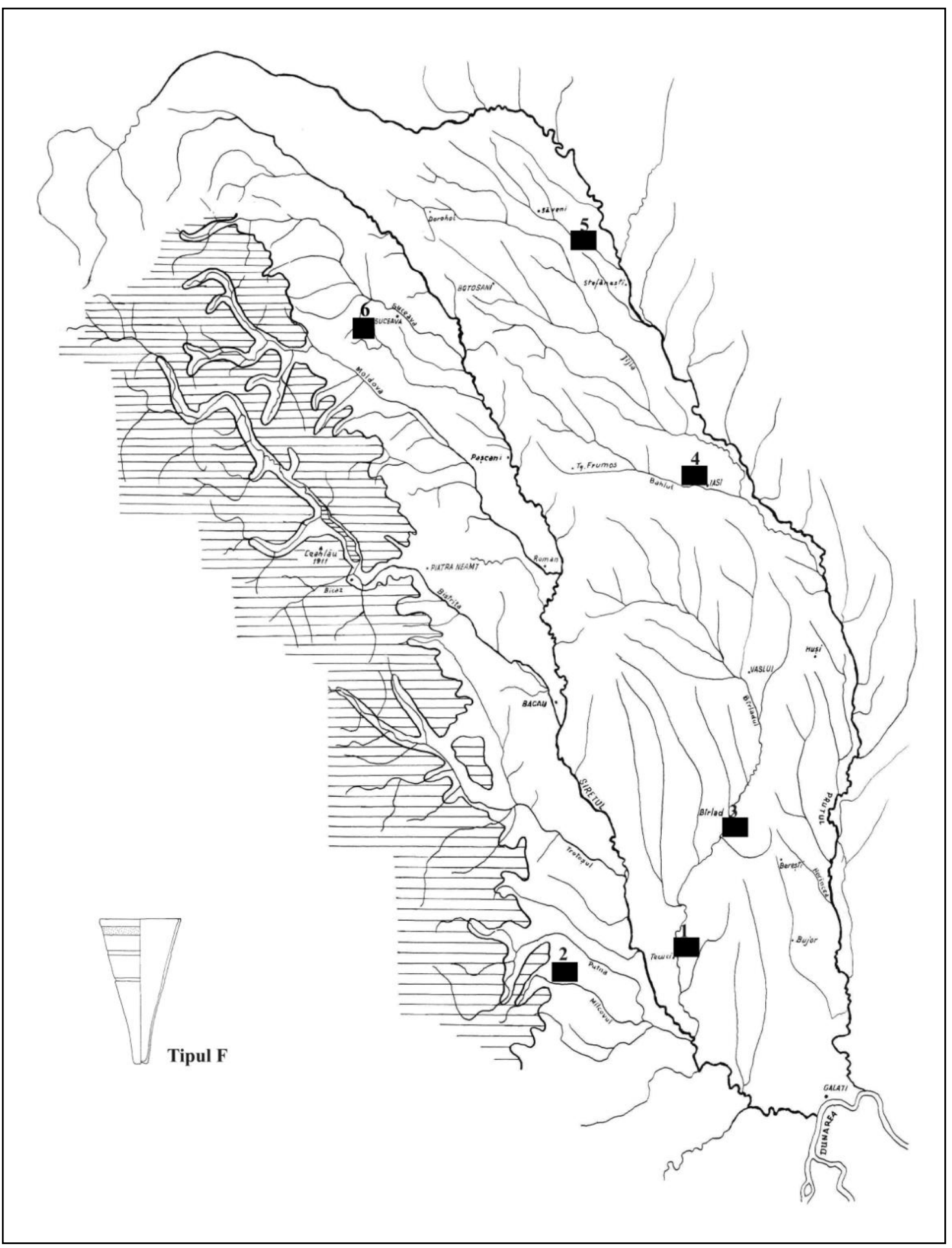

Fig. 14. Distribution of F- type beakers. 1. Barcea; 2. Mărtineşti; 3. Bârlad - Valea Sacă; 4. Lețcani; 5. Mihălăşeni, 6. Moara 